\title{
In vitro and in silico tools to assess extent of cellular uptake and lysosomal sequestration of respiratory drugs in human alveolar macrophages
}

DOI:

10.1021/acs.molpharmaceut.6b00908

\section{Document Version}

Accepted author manuscript

Link to publication record in Manchester Research Explorer

Citation for published version (APA):

Ufuk, A., Assmus, F., Francis, L., Plumb, J., Damian, V., Gertz, M., Houston, J., \& Galetin, A. (2017). In vitro and in silico tools to assess extent of cellular uptake and lysosomal sequestration of respiratory drugs in human alveolar macrophages. Molecular Pharmaceutics, 14(4), 1033-1046. https://doi.org/10.1021/acs.molpharmaceut.6b00908

\section{Published in:}

Molecular Pharmaceutics

\section{Citing this paper}

Please note that where the full-text provided on Manchester Research Explorer is the Author Accepted Manuscript or Proof version this may differ from the final Published version. If citing, it is advised that you check and use the publisher's definitive version.

\section{General rights}

Copyright and moral rights for the publications made accessible in the Research Explorer are retained by the authors and/or other copyright owners and it is a condition of accessing publications that users recognise and abide by the legal requirements associated with these rights.

\section{Takedown policy}

If you believe that this document breaches copyright please refer to the University of Manchester's Takedown Procedures [http://man.ac.uk/04Y6Bo] or contact uml.scholarlycommunications@manchester.ac.uk providing relevant details, so we can investigate your claim.

\section{OPEN ACCESS}


This document is confidential and is proprietary to the American Chemical Society and its authors. Do not copy or disclose without written permission. If you have received this item in error, notify the sender and delete all copies.

\section{In vitro and in silico tools to assess extent of cellular uptake and lysosomal sequestration of respiratory drugs in human alveolar macrophages}

\begin{tabular}{|r|l|}
\hline Journal: & Molecular Pharmaceutics \\
\hline Manuscript ID & mp-2016-009082.R1 \\
\hline Manuscript Type: & Article \\
\hline Date Submitted by the Author: & 17-Jan-2017 \\
\hline Complete List of Authors: & $\begin{array}{l}\text { Ufuk, Ayş; Centre for Applied Pharmacokinetic Research, Division of } \\
\text { Pharmacy and Optometry } \\
\text { Assmus, Frauke; Centre for Applied Pharmacokinetic Research, Division of } \\
\text { Pharmacy and Optometry } \\
\text { Francis, Laura; Centre for Applied Pharmacokinetic Research, Division of } \\
\text { Pharmacy and Optometry } \\
\text { Plumb, Jonathan; University Hospital of South Manchester NHS Foundation } \\
\text { Trust, Respiratory and Allergy Clinical Research Facility } \\
\text { Damian, Valeriu; GlaxoSmithKline USA, Computational Modeling Sciences, } \\
\text { DDS } \\
\text { Gertz, Michael; F Hoffmann-La Roche AG, Pharmaceutical Sciences, pRED } \\
\text { Houston, J. Brian; Centre for Applied Pharmacokinetic Research, Division of } \\
\text { Pharmacy and Optometry } \\
\text { Galetin, Aleksandra; Centre for Applied Pharmacokinetic Research, Division } \\
\text { of Pharmacy and Optometry }\end{array}$ \\
\hline
\end{tabular}




\title{
In vitro and in silico tools to assess extent of cellular uptake and lysosomal sequestration of respiratory drugs in human alveolar macrophages
}

\author{
Ayşe Ufuk ${ }^{1}$, Frauke Assmus ${ }^{1}$, Laura Francis ${ }^{1}$, Jonathan Plumb ${ }^{2}$, Valeriu Damian ${ }^{3}$, Michael \\ Gertz $^{1,4}$, J. Brian Houston ${ }^{1}$ and Aleksandra Galetin ${ }^{1 *}$ \\ ${ }^{1}$ Centre for Applied Pharmacokinetic Research, School of Health Sciences, University of \\ Manchester, Manchester, UK \\ ${ }^{2}$ Respiratory and Allergy Clinical Research Facility, University Hospital of South Manchester \\ ${ }^{3}$ Computational Modeling Sciences, DDS, GlaxoSmithKline, Upper Merion, USA \\ ${ }^{4}$ Pharmaceutical Sciences, pRED, Roche Innovation Center, Basel, Switzerland
}

KEYWORDS Human alveolar macrophages, NR8383, drug accumulation, lysosomal sequestration, in silico cell model

*Correspondence author: Aleksandra.Galetin@manchester.ac.uk 


\begin{abstract}
Accumulation of respiratory drugs in human alveolar macrophages (AMs) has not been extensively studied in vitro and in silico despite its potential impact on therapeutic efficacy and/or occurrence of phospholipidosis. The current study aims to characterize the accumulation and subcellular distribution of drugs with respiratory indication in human AMs and to develop an in silico mechanistic AM model to predict lysosomal accumulation of investigated drugs. The dataset included 9 drugs previously investigated in rat AM cell line NR8383. Cell-to-unbound medium concentration ratio $\left(\mathrm{K}_{\mathrm{p}, \text { cell }}\right)$ of all drugs $(5 \mu \mathrm{M})$ was determined to assess the magnitude of intracellular accumulation. The extent of lysosomal sequestration in freshly isolated human AMs from multiple donors $(n=5)$ was investigated for clarithromycin and imipramine (positive control) using indirect in vitro method $\left( \pm 20 \mathrm{mM}\right.$ ammonium chloride, $\left.\mathrm{NH}_{4} \mathrm{Cl}\right)$. The $\mathrm{AM}$ cell parameters and drug physicochemical data were collated to develop an in silico mechanistic AM model. Three in silico models differing in their description of drug membrane partitioning were evaluated; model (1) relied on octanol-water partitioning of drugs, model (2) used in vitro data to account for this process, and model (3) predicted membrane partitioning by incorporating AM lipid fractions. In vitro $\mathrm{K}_{\mathrm{p} \text {,cell }}$ ranged $>200$-fold for respiratory drugs, with the highest accumulation seen for clarithromycin. A good agreement in $\mathrm{K}_{\mathrm{p}, \mathrm{cell}}$ was observed between human AMs and NR8383 (2.45-fold bias), highlighting NR8383 as a potentially useful in vitro surrogate tool to characterize drug accumulation in AMs. The mean $\mathrm{K}_{\mathrm{p}, \text { cell }}$ of clarithromycin $(81, \mathrm{CV}=51 \%)$ and imipramine $\left(963, \mathrm{CV}=54 \%\right.$ ) were reduced in the presence of $\mathrm{NH}_{4} \mathrm{Cl}$ by up to $67 \%$ and $81 \%$, respectively, suggesting substantial contribution of lysosomal sequestration and intracellular binding in the accumulation of these drugs in human AMs. The in vitro data showed substantial variability in drug accumulation between individual human AM donors due to possible
\end{abstract}


differences in lysosomal abundance, volume and phospholipid content, which may have important clinical implications. Consideration of drug-acidic phospholipid interactions significantly improved the performance of the in silico models; use of in vitro $\mathrm{K}_{\mathrm{p}, \text { cell }}$ obtained in the presence of $\mathrm{NH}_{4} \mathrm{Cl}$ as a surrogate for membrane partitioning (model 2), captured the variability in clarithromycin and imipramine $\mathrm{K}_{\mathrm{p}, \mathrm{cell}}$ observed in vitro and showed the best ability to predict correctly positive and negative lysosomotropic properties. The developed mechanistic AM model represents a useful in silico tool to predict lysosomal and cellular drug concentrations based on drug physicochemical data and system specific properties, with potential application to other cell types.

\section{INTRODUCTION}

Increased uptake of drugs by AMs may result in suboptimal efficacy for drugs with extracellular targets and potential adverse effects including phospholipidosis that may compromise patients' safety. The latter is associated with lysosomal sequestration of lipophilic amine drugs in AMs which may contribute significantly to their total intracellular concentrations and consequently distribution in tissues rich in lysosomes such as lungs, liver and kidneys ${ }^{1}$. In addition to the induction of phospholipidosis, the role of this process in drug efficacy and potential involvement in drug resistance and drug-drug interactions has been highlighted ${ }^{2-7}$. Although total intracellular drug concentrations can be measured and related to external media drug concentrations, determination of unbound cytosolic and lysosomal concentrations is experimentally challenging. While there is an increased interest in understanding intracellular distribution of drugs, investigation of lysosomal sequestration in AMs has remained limited despite their anticipated important contribution to the overall lung drug disposition. Recently, lysosomal sequestration 
has been proposed to lead to the retention and prolonged duration of action of a number of inhaled beta-adrenergic bronchodilators in the $\mathrm{lung}^{8}$ where lysosome rich AMs are likely to be the key contributors. Consequently, use of in silico mechanistic models accounting for system and drug properties may be useful in providing dynamic assessment of intracellular concentrations and several processes occurring in cells such as transporter-mediated uptake/efflux, passive diffusion, metabolism, intracellular binding and lysosomal sequestration. While no mechanistic model has incorporated all of these processes for a particular system so far, a number of studies have successfully captured one or more processes in a specific cell type or tissue ${ }^{9-15}$. The earlier work of Trapp and colleagues ${ }^{16}$ have demonstrated the prediction of subcellular (mitochondria and lysosomes) distribution of model acidic, basic and zwitterionic compounds in a generic cell model, based on passive permeation of neutral and ionized species in consideration of membrane potentials and intracellular $\mathrm{pH}$ gradients ${ }^{16,17}$. However, these models have not been adapted for a specific cell type and have not captured the interactions of the ionized forms of basic drugs with the membrane acidic phospholipids (AP), highlighted as an important contributor to intracellular accumulation of basic drugs and their partitioning in membranes $^{13,18}$.

Although a number of studies have investigated uptake and lysosomal sequestration of drugs in rat primary AMs and cell lines such as $\mathrm{NR} 8383^{19-25}$, there has been no attempt to characterize this process in human AMs. One of the aims of this study was to investigate intracellular accumulation of a range drugs with respiratory indication and both extra- and intracellular targets in human AMs. Drugs included in the study were clarithromycin, formoterol, terbutaline, fenoterol, rifampicin, budesonide, ipratropium and tiotropium bromide, as analyzed previously by our group in $\mathrm{NR} 8383^{25}$. Furthermore, lysosomal sequestration of clarithromycin and the 
prototypical lysosomotropic drug imipramine (positive control) ${ }^{26}$ was investigated in human AMs freshly isolated from different patient donors to evaluate the inter-individual variability in this process. The in vitro data in human AMs were compared to those previously obtained in NR8383 cells ${ }^{25}$ to assess the validity of this cell line as an in vitro tool for the prediction of drug accumulation in human AMs. In addition to the in vitro assessment, the generic in silico cell model reported by Trapp et al. (2008) ${ }^{16}$ was modified by incorporating cell parameters specific for human AMs (e.g., lysosomal volume, $\mathrm{pH}$ of different organelles) and relevant drug physicochemical properties $(\log \mathrm{P}, \mathrm{pKa})$; lipid partitioning and electrostatic interactions were also accounted for. The developed in silico AM model was subsequently assessed as a tool to predict drug accumulation in human AMs and particularly in lysosomes using the dataset of investigated respiratory drugs. Three subtypes of the in silico AM model were evaluated; the models only differed in their description of drug interaction with membrane phospholipids. Cellular accumulation (as assessed by cell-to-unbound medium concentration ratio, $\mathrm{K}_{\mathrm{p}, \mathrm{cell}}$ ) and extent of lysosomal sequestration of drugs predicted by the in silico AM models were compared to the experimental data obtained in human AMs and the NR8383 cell line using indirect methods.

\section{MATERIALS AND METHODS}

\section{Chemicals and Reagents}

1-Aminobenzotriazole, ammonium chloride, ciprofoxacin, clarithromycin, dimethyl sulphoxide, imipramine, lactate dehydrogenase activity assay kit, Trypan blue $0.4 \%$ and verapamil hydrochloride were all from Sigma Aldrich Ltd., Dorset, UK. Budesonide, ipratropium bromide, fenoterol, formoterol, terbutaline and tiotropium bromide were all supplied by GlaxoSmithKline, UK. Chloroform and formaldehyde 37-41\% were from Fisher Scientific, Loughborough, UK. 
Further chemicals include diazepam (Tocris Bioscience, Bristol, UK), methanol (VWR, UK), midazolam (Hoffman La Roche, Switzerland), Pierce BCA protein assay kit (Thermo Scientific, Loughborough, UK) and Lysotracker ${ }^{\circledR}$ Red DND-99 (Life Technologies, Paisley, UK). Reagents include bovine serum albumin, penicillin-streptomycin and Roswell Park Memorial Institute (RPMI)-1640 medium (Sigma Aldrich Ltd., Dorset, UK), collagen Type I rat tail (BD Biosciences, Oxford, UK), Dulbecco's phosphate buffered saline, heat-inactivated foetal bovine serum and $200 \mathrm{mM}$ L-glutamine (Life Techonolgies, Paisley, UK), Ficoll-paque (GE Healthcare, Buckinghamshire, UK) and Kaighn's modification of Ham's F12 (Ham's F12K) medium (American Tissue Culture Collection (ATCC), Mannasas, VA, USA).

\section{Source and preparation of human alveolar macrophages}

The human alveolar macrophages were obtained from patients undergoing lung surgery at the Respiratory and Allergy Clinical Research Facility in the University Hospital of South Manchester NHS Foundation Trust. The study was approved by South Manchester Research Ethics Committee and all subjects gave written informed consent to participate. Nine patients undergoing surgical resection for suspected or confirmed lung cancer were recruited for human alveolar macrophage assays. Patients were categorized as either smokers ( $\geq 1$ pack year history) or non-smokers ( $<1$ pack year history). All patients with the exception of one had normal lung function as predicted forced expiratory volume in 1 second FEV1, $>80 \%$, and FEV1/Forced vital capacity (FVC) ratio, $>70 \%$ (Table S1, Supporting Information). All patients were known to be free from any medications at the time of surgery except one patient who had salbutamol in medication history; details of medication prior to surgery were unknown. 
The isolation of the cells from the lung surgery sections was performed as described briefly herein: Areas of lung distant from the tumour were perfused with $0.1 \mathrm{M}$ sodium chloride. The resulting cell suspension was centrifuged ( $400 \mathrm{~g}$, for 10 minutes, at room temperature) and the cell pellet was re-suspended in RPMI-1640 medium. The cells were layered over a Ficoll-paque gradient. The mononuclear cells at the Ficoll interface were extracted, washed and re-suspended in the complete growth medium (CGM): RPMI-1640 medium containing $10 \% \mathrm{v} / \mathrm{v} \mathrm{FBS,} 1 \% \mathrm{v} / \mathrm{v}$ $200 \mathrm{mM}$ L-glutamine, 1\% v/v 100 units $/ \mathrm{ml}$ penicillin and $100 \mu \mathrm{g} / \mathrm{ml}$ streptomycin. Following isolation, the cells were maintained in this CGM in the fridge before the start of the experiments. All experiments were initiated within 24 hours of surgery. The growth medium covering the macrophage cell monolayers was replaced with fresh medium before the start of the accumulation experiments in order to remove any remaining red blood cells. Further details on the AM isolation method and characterization of AM phenotype and activation state from resected lung tissue have been reported previously ${ }^{27-29}$.

\section{In vitro accumulation and lysosomal sequestration of drugs in human AMs}

In the current study, the accumulation of 9 drugs was assessed in human AMs using the method adapted from previous study in NR8383 cells ${ }^{25}$. Following the isolation and re-suspension of the cells in $1 \mathrm{~mL}$ CGM, the cell count and viability were assessed with Trypan-blue exclusion method using a haemocytometer under the light microscope (Leica Microsystems ATC2000, Milton Keynes, UK). The cells were then further supplemented with the CGM and $0.4 \mathrm{~mL}$ of the cell suspension was dispensed into collagen-I coated 24-well plates (BD Biosciences, Oxford, UK), seeding the wells at a density of $0.4 \times 10^{6}$ cells $\left(0.3 \times 10^{6}\right.$ in cases of insufficient number of cells). This seeding density was selected to accommodate the experimental set up that included 
several washing steps before accumulation studies and detachment of a substantial number of cells from the wells ( $\sim 30 \%$ of the initial seeding density). After 2 hours of plating the cells at $37^{\circ} \mathrm{C}, 5 \% \mathrm{CO}_{2}$ incubator $\left(\mathrm{CO}_{2}\right.$ incubator, $\mathrm{MCO}-17 \mathrm{AIC}$, Sanyo Biomedical, Loughborough, UK), the existing medium was replaced with the pre-warmed fresh medium to remove any unattached cells other than AMs which remained after their isolation. The plates were returned to the $37^{\circ} \mathrm{C}$ incubator and cultured for another 2 hours before the start of the uptake experiments. At this culture time, the cells were $>70 \%$ confluent in wells and almost completely attached to the collagen support. The accumulation experiments at $37^{\circ} \mathrm{C}$ were performed on a single occasion for each drug investigated except for clarithromycin and imipramine (multiple donors). The investigation of lysosomal sequestration of basic drugs using ammonium chloride $\left(\mathrm{NH}_{4} \mathrm{Cl}\right)$ was performed as described previously ${ }^{25}$. Among the drug dataset, clarithromycin was selected for the assessment of lysosomal sequestration in human AMs, following positive findings in NR8383 cells. In addition, imipramine was included as a positive control, consistent with experiments in NR8383. All cell lysates and media samples were kept at $-20^{\circ} \mathrm{C}$ overnight before analysis by LC-MS/MS. The amount of protein in each well was measured to determine the cell number using BCA protein assay.

\section{Sample preparation and mass spectrometry analysis}

Preparation and analysis of the cell lysate and media samples, and quantification of drug concentrations by LC-MS/MS were the same as in the previous study ${ }^{7}$. A calibration standard, containing the drug of investigation at a concentration range covering that of the experimental samples with an additional zero blank, was prepared in the same matrix of the experimental samples when sufficient number of human AMs was provided. When this was not the case, 
NR8383 cell lysates were used; a matrix made of NR8383 cells was considered to be the closest to human AMs due to the use of the same cell type.

\section{Determination of drug accumulation}

Accumulation of drugs in human AMs was determined by calculating $\mathrm{K}_{\mathrm{p} \text {,cell }}$ at $5 \mu \mathrm{M}$ drug concentration at 10 minutes from the cell-to-unbound medium concentration ratio ${ }^{30,31}$. In cases where measured media concentrations were not available, nominal media concentration (i.e., 5 $\mu \mathrm{M})$ was used. The cell volume used to calculate the total cell concentration of the drugs in human AMs was $2.2 \mu \mathrm{L} / 10^{6}$ cells. This value represents the mean of a number of morphometric studies reporting AM cell volume in healthy smoker and non-smoker subjects (references listed in Table 1). Previous literature reporting cell volume (Table 1) or cell diameter ${ }^{32-34}$ indicated no signficant difference between the size of AMs from smokers $\left(1.9 \mu \mathrm{L} / 10^{6}\right.$ cells $)$ and non-smokers ( $2.4 \mu \mathrm{L} / 10^{6}$ cells), hence the average cell volume from both populations were used. The interindividual variability in clarithromycin and imipramine $\mathrm{K}_{\mathrm{p}, \mathrm{cell}}$ was assessed.

\section{Determination of lysosomal sequestration}

Lysosomal sequestration of clarithromycin and imipramine in human AMs was determined using indirect method based on the assumption that $\mathrm{NH}_{4} \mathrm{Cl}$ abolishes $\mathrm{pH}$ gradient between cytosol and lysosomes. The advantages and limitations of indirect methods have been discussed previously ${ }^{25}$. $\mathrm{K}_{\mathrm{p}, \text { cell }}$ in the presence and absence of $\mathrm{NH}_{4} \mathrm{Cl}$ was determined in at least same 4 donors of AMs for both drugs. The reduction in $\mathrm{K}_{\mathrm{p} \text {,cell }}$ of each drug in the presence of $\mathrm{NH}_{4} \mathrm{Cl}$ was expressed as a percentage relative to control and used as an indicator of the extent of lysosomal sequestration in human AMs. 


\title{
Statistical analysis
}

The arithmetic mean, standard error and coefficient of variation $(\mathrm{CV})$ were calculated for $\mathrm{K}_{\mathrm{p} \text {,cell }}$ where the data were determined on more than one occasion. Geometric mean fold error (gmfe) was calculated (Eq. 1) in order to assess the discrepancy between NR8383 and human AM $K_{\text {p,cell }}$ data.

$$
\text { gmfe }=10 \frac{1}{N} \sum\left|\log \frac{\text { predicted }}{\text { observed }}\right|
$$

where $\mathrm{N}$ is the number of observations. When assessing lysosomal sequestration, the control and $\mathrm{NH}_{4} \mathrm{Cl}$ treated cells were compared using the two-tailed, paired t-test in order to determine the existence of a statistically significant difference between the two conditions. The data were considered to be statistically significant when $p<0.05$.

\begin{abstract}
Assessment of lysosomal sequestration in human AMs using Lysotracker ${ }^{\circledR}$ Red (LTR) Localization of lysosomes and assessment of lysosomal sequestration in human AMs were performed as previously ${ }^{25}$ with a minor change in the seeding density of human AMs in collagen-I coated Ibidi 8-well chamber slides (200,000 cells/well). Following the procedure, the cells were examined for the detection of LTR with a confocal laser scanning microscope (Zeiss LSM 510, Jena, Germany). The details of this system, image processing and the quantification of LTR fluorescence intensity were as reported previously ${ }^{7}$.
\end{abstract}

\begin{abstract}
Assessment of cytotoxicity of $\mathrm{NH}_{4} \mathrm{Cl}$ in human $\mathrm{AMs}$
The incubation medium consisting of $5 \mu \mathrm{M}$ clarithromycin and imipramine in the absence and presence of $20 \mathrm{mM} \mathrm{NH}_{4} \mathrm{Cl}$ were tested for cytotoxicity using the LDH assay kit (Sigma-Aldrich, Dorset, UK). Extensive assessment of cytotoxicity including the effect of $\mathrm{NH}_{4} \mathrm{Cl}$ alone on the
\end{abstract}


cells could not be performed due to limited number of human AMs. The assessment of the cytotoxicity of $\mathrm{NH}_{4} \mathrm{Cl}$ presented in the incubation medium containing clarithromycin or imipramine showed that the LDH activity of the samples was $<1 \%$ compared to $100 \%$ of the positive control, indicating that no cytotoxicity was associated with $\mathrm{NH}_{4} \mathrm{Cl}$ in human $\mathrm{AMs}$ under conditions used.

\section{In silico alveolar macrophage model}

The mechanistic in silico AM model consists of 4 compartments, namely extracellular medium, cytosol, mitochondria and lysosomes. The cell compartments are associated with an aqueous and lipid fraction and surrounded by a membrane. In the model, drug accumulation in the cell and sub-cellular compartments occurs via passive diffusion of neutral and ionized species, with ionized species showing reduced permeability. In addition to concentration gradients, membrane potentials are taken into account, which have been suggested to drive the diffusive flux of ionized species ${ }^{16}$. Differences in drug ionization according to $\mathrm{pH}$ differences between medium, cytosol, lysosomes and mitochondria are likewise considered (pH partitioning), along with drug partitioning of neutral and ionized species into cell and organelle membranes. The model development was supported by collation of literature reported relevant cell parameters for AMs; details of parameters are listed in Table 1. The distribution of a basic drug in AMs involving these processes is illustrated in Figure 1. 


\section{Flux of neutral and ionized drug species across membranes}

The total diffusive flux of drugs across membranes was described as the sum of the flux of neutral (Fick's $1^{\text {st }}$ Law of Diffusion) and ionized (Nernst-Planck equation) species according to Eq. 2:

$$
J=P_{N}\left(C_{N, \text { out }}-C_{N, \text { in }}\right)+P_{D} \times \frac{N}{e^{N}-1}\left(C_{D, \text { out }}-C_{D, \text { in }} \times e^{N}\right)
$$

where $P$ is permeability, $C$ is concentration, $N=z E_{m} F /(R T) ; z$ is the electric charge of ionic species, $E_{m}$ is the membrane potential (V), $F$ is the Faraday constant $\left(96,484.56{\mathrm{C} . \mathrm{mol}^{-1}}^{-1}\right), R$ is the universal gas constant $\left(8.314 \mathrm{~J} \cdot \mathrm{mol}^{-1} \cdot \mathrm{K}^{-1}\right)$ and $T$ is the absolute temperature $(310.16 \mathrm{~K})^{16}$. The subscripts $N$ and $D$ represent neutral and dissociated (ionized) species, respectively.

\section{Membrane permeability}

The membrane permeability was predicted, assuming drug partitioning into membranes was adequately defined by partitioning into octanol. The permeability of neutral species $\left(P_{N}\right)$ across

membranes was described by Eq. 3. where $D C$ is the diffusion coefficient $\left(10^{-14} \mathrm{~m}^{2} \mathrm{~s}^{-1}\right.$ for all drugs), $K_{\text {ow }}$ is the octanol-water partition coefficient of neutral species and $d x$ is the membrane thickness.

$$
P_{N}=\frac{D C \times K_{o w}}{d x}
$$

Regarding the permeability of ionized species, a further $3.5 \log$ unit reduction in lipophilicity was included as a penalty term for every charge a drug molecule possessed (e.g., 3.5 and $7 \log$ unit for mono and diprotic drugs, respectively) ${ }^{16}$. 


\section{Membrane partitioning}

Three subtypes of in silico AM model were explored; the physiological structure and parameters of these models were the same with the exception of the description of membrane partitioning of drugs, as summarized in Table 2. In the AM model (1), drug partitioning into membranes was based on the assumption that this process is adequately defined by drug partitioning into octanol $^{16}$. Taking the lipid content of the cells into consideration, total drug partitioning into membrane lipids was described by Eq. 4.

$$
K=L \times K_{o w}+L \times K_{o w, D}
$$

where $L$ is the fractional lipid content ( $\mathrm{vol} / \mathrm{vol}), K_{o w}$ and $K_{o w, D}$ are the octanol-water partition coefficients of neutral and ionized species. The fractions of neutral $\left(f_{N}\right)$ and ionized $\left(f_{D}\right)$ species based on Henderson-Hasselbalch principles (Eq. S1-7, Supporting Information) and membrane partitioning were subsequently used in equations describing the fractions of neutral (Eq. 5) and ionized (Eq. S8, Supporting Information) species in cell model compartments.

$$
F_{N}=\frac{C_{N, f}}{C_{T}}=\left(W+L \times K_{o w}+\sum_{i}^{n}\left(\frac{f_{D i} \times W}{f_{N}}+\frac{f_{D i} \times L \times K_{o w}}{f_{N}}\right)\right)^{-1}
$$

where $C_{N, f}$ and $C_{T}$ are concentration of neutral species which can freely permeate membranes and the total concentration, respectively, $W$ is the fractional water content (vol/vol). The Eq. 5 provides an example for a monoprotic drug, however can be extended to cover drugs with multiple charges e.g., $i$ is indicates the existence of ionized species and $n$ is the number of ionized species.

In contrast to AM model (1), AM model (2) takes into account interactions of cationic drug species with acidic phospholipids. Therefore, the term " $\mathrm{LxK}_{\mathrm{ow}}$ " in Eq. 4 was replaced with 
experimentally determined cell-to-unbound medium concentration ratio obtained in the presence of $\mathrm{NH}_{4} \mathrm{Cl}\left(\mathrm{K}_{\mathrm{p}+\mathrm{NH} 4 \mathrm{Cl}}\right)$ (Eq. S9, Supporting Information). The rationale for this approach was that in the presence of $\mathrm{NH}_{4} \mathrm{Cl}$, lysosome-cytosol $\mathrm{pH}$ gradient is diminished and the remaining intracellular accumulation was assumed to reflect membrane partitioning (i.e., minimal active uptake). Alternatively, the minimum cell-to-unbound medium partition coefficient $\left(\mathrm{K}_{\mathrm{p}, \min }\right)$, representing drug partition into membranes when active processes are saturated at high substrate concentration $^{18}$ can be used for this purpose. This approach was not feasible here due to limited availability of human AMs. In the case of basic drugs in the dataset $\left(\mathrm{pK}_{\mathrm{a}}>8\right)$ ionized species will contribute predominantly to $\mathrm{K}_{\mathrm{p}+\mathrm{NH} 4 \mathrm{Cl}}$ due to their extensive ionization at physiological $\mathrm{pH}$. Therefore, it was assumed that $\mathrm{K}_{\mathrm{p}+\mathrm{NH} 4 \mathrm{Cl}}$ represents the distribution of ionized species between the membrane and aqueous compartments. To account for the distribution of neutral species (equivalent of $\log \mathrm{P}$ ), $\mathrm{K}_{\mathrm{p}+\mathrm{NH} 4 \mathrm{Cl}}$ was extrapolated to $\mathrm{K}_{\mathrm{p}+\mathrm{NH} 4 \mathrm{Cl}, \mathrm{n}}$ by assigning $1.0 \log$ unit higher distribution for the latter. This difference between the distribution of neutral and ionized species was within the range of values (0-1.8) reported for basic drugs assessed in liposomes as closer membrane mimetic than octanol ${ }^{35-43}$. Once $\mathrm{K}_{\mathrm{p}+\mathrm{NH} 4 \mathrm{Cl}, \mathrm{n}}$ was defined, a $1.0 \mathrm{log}$ unit penalty in partitioning was applied for every charge of the drug molecule. The $\mathrm{K}_{\mathrm{p}}$ data were then used in equations describing the fractions of neutral (Eq. S9, Supporting Information) and ionized (Eq. S8, Supporting Information) species in each cell model compartment.

In contrast to above, membrane partitioning was predicted in the AM model (3) by incorporating the cell specific AP concentration (mg/g cell) and the association constant of cationic drugs with AP $\left(\mathrm{K}_{\mathrm{a}}\right)$ using the Rodgers \& Rowland model ${ }^{1}$. Furthermore, the interaction of neutral drug with the fraction of neutral phospholipids (NP) and neutral lipids (NL) was considered. Consequently, 
the equations describing the fraction of neutral (Eq. S10) and ionized (Eq. S8) drugs in each compartment were revised (Table 2). Binding of cationic drugs to NL and NP was neglected.

\section{Parameterization and assumptions of the in silico AM model}

The in silico AM model was parameterized using both AM cell and drug specific parameters. The AM cell parameters were collated from available literature; details are listed in Table 1. Most of the data were collated in human (non-smoker and smoker) and rat AMs with the exception of $\mathrm{pH}$ and $\mathrm{E}_{\mathrm{m}}$ of which the majority of the data was from primary macrophages or macrophage cell lines of other species, or other cell types including rat hepatocytes. Lysosomal $\left(\mathrm{V}_{\text {lys }}\right)$ and mitochondrial $\left(\mathrm{V}_{\text {mit }}\right)$ volumes in human AMs were calculated from the information that lysosomes contribute $9.3 \%$ on average (ranged $5.8-13.6 \%, \mathrm{CV}<30 \%$ ) to the total cell volume $\left(\mathrm{V}_{\text {cell }}\right)$, whereas contribution of mitochondria is 3.8\% (ranged 3.0-4.9\%, CV<30\%) in rat AMs (Table S2, Supporting Information), assuming the volume fractions were the same in both systems. The surface area of both cell and organelles were calculated from the volume of the respective compartments, assuming they were spheres. In general, the fractional lipid and water content of the cell and organelles were 0.05 and $0.95 \mathrm{vol} / \mathrm{vol}$, respectively ${ }^{16,17}$. In the AM model (3) where the volume fractions of AP (0.0123), NP (0.0549) and NL (0.0188) were considered ${ }^{44,}$

45, the lipid and water contents were 0.0860 (sum of lipid fractions) and 0.914 (1-sum of lipid fractions), respectively. The AP concentration of AMs was $12.34 \mathrm{mg} / \mathrm{g}$ of cell ${ }^{44,45}$ and the AP composition of lysosomal, mitochondrial and plasma membrane was assumed to be the same. The plasma and organelle membrane thickness of AMs was assigned as $9 \mathrm{~nm}$, generic to plasma membranes ${ }^{46}$. 
The drug specific parameters were the octanol-water partition coefficient, LogP, acid-base dissociation constant(s), $\mathrm{pK}_{\mathrm{a}}$ (Table 3), $\mathrm{K}_{\mathrm{a}}$ and $\mathrm{K}_{\mathrm{p}+\mathrm{NH} 4 \mathrm{Cl}}$ (Table S3, Supporting Information for data in human AMs and Ufuk et al. $(2015)^{25}$ for data in NR8383). As the $\mathrm{K}_{\mathrm{a}}$ data were not readily available, this parameter was calculated for red blood cells $\left(\mathrm{K}_{\mathrm{a}, \mathrm{BC}}\right.$, Table $\mathrm{S} 4$, Supporting Information) which also contain AP and assumed that it was representative of the $\mathrm{K}_{\mathrm{a}}$ in $\mathrm{AMs}$, as done previously ${ }^{1}$. In cases where negative $\mathrm{K}_{\mathrm{a}, \mathrm{BC}}$ values were obtained, the association of the drug with blood cells was assumed to be negligible and this parameter was set to zero. In vitro $\mathrm{K}_{\mathrm{p}+\mathrm{NH} 4 \mathrm{Cl}}$ was not available for all individual AM donors; in those cases the average \% lysosomal contribution to the accumulation of clarithromycin and imipramine in human AMs was used to estimate $\mathrm{K}_{\mathrm{p}+\mathrm{NH} 4 \mathrm{Cl}}$ and for the prediction of $\mathrm{K}_{\mathrm{p} \text {,cell }}$ in AM model (2) (Table S5, Supporting Information). Subsequently, the inter-individual variation in predicted $\mathrm{K}_{\mathrm{p} \text {,cell }}$ of both drugs was assessed.

\section{In silico cell model outputs}

The in silico AM models were used to predict intracellular concentrations of the respiratory drugs, including also concentrations in lysosomes, mitochondria and cytosol. Drug concentrations in all AM model compartments were predicted at steady-state when net flux was zero. Differential equation describing changes in lysosomal drug concentration is illustrated in Eq. 6, whereas equations for remaining cellular compartments (e.g., cytosol, mitochondria) are shown in the Supporting Information (Eq. S11-14).

$$
\begin{aligned}
& \frac{d C_{l}}{d t}=\left(\left(C_{c} \times F_{N c} \times P_{N} \times S A_{l} \times N_{c e l l} \times N_{l}\right)+\left(C_{c} \times F_{D c} \times P_{D} \times \frac{N}{e^{N-1}} \times S A_{l} \times N_{c e l l} \times N_{l}\right)-\right. \\
& \left.\left(C_{l} \times F_{N l} \times P_{N} \times S A_{l} \times N_{c e l l} \times N_{l}\right)-\left(C_{l} \times F_{D l} \times P_{D} \times \frac{N}{e^{N-1}} \times S A_{l} \times N_{c e l l} \times N_{l}\right)\right) / V_{l}
\end{aligned}
$$


where $C, F, P, S A, V$ and $N$ represent concentration, fraction, permeability, surface area, volume and number, respectively and the subscripts $N, D$, med, cell, $c, l$ and $m$ represent neutral, ionized, medium, total cell, cytosol, lysosomes and mitochondria, respectively. The total cell concentration was the sum of cytosolic, lysosomal and mitochondrial concentrations. The N/e $\mathrm{e}^{\mathrm{N}}-1$ ratio represents Nernst Plank equation ${ }^{16}$. The cell and organelle number was 1.

The numerical solution of the implemented equations was performed using ordinary differential equation 15 (ODE15i) solver in Matlab v7.14 ${ }^{\circledR}$ (2012). The predicted concentrations were used to derive $K_{p}$ for each compartment. The model predicted $K_{p}$ values can be expressed relative to cytosol or the external medium; the latter was the case for the current work to allow direct comparison with experimental data. The prediction of the extent of lysosomal sequestration was performed by increasing lysosomal $\mathrm{pH}$ to 7.2 in the in silico AM model to mimic the presence of $\mathrm{NH}_{4} \mathrm{Cl}$ and complete abolishment of cytosol-lysosome $\mathrm{pH}$ gradient (as done experimentally). The predicted and observed \% contribution of lysosomes to intracellular accumulation (estimated from the \% reduction in $\mathrm{K}_{\mathrm{p} \text {,cell }}$ in the presence of $\mathrm{NH}_{4} \mathrm{Cl}$ ) were compared.

\section{Assessment of the in silico AM model performance}

Ability of the model to classify drugs as lysosomotropic was investigated by using the $30 \%$ of reduction in $\mathrm{K}_{\mathrm{p} \text {,cell }}$ in the presence of $\mathrm{NH}_{4} \mathrm{Cl}$ as a cut-off. True Positive (TP, predicted and observed: $>30 \%)$ and Negative (TN, predicted and observed: $<30 \%)$ indicate that the in silico model could correctly predict the extent of lysosomal sequestration observed for the investigated drugs. False Positive (FP, predicted: $>30 \%$, observed: $<30 \%$ ) and Negative (FN, predicted: $<30 \%$, observed: $>30 \%$ ) indicate the in silico model predicted incorrectly the extent of lysosomal sequestration observed for the drugs investigated. In addition, the sensitivity $(\mathrm{TP} /(\mathrm{TP}+\mathrm{FN}))$, 
specificity $((\mathrm{TN} / \mathrm{TN}+\mathrm{FP})$, false negative $((\mathrm{FN} /(\mathrm{TP}+\mathrm{FN}))$ and positive $((\mathrm{FP} /(\mathrm{TN}+\mathrm{FP}))$ rates, and negative $((\mathrm{FN} /(\mathrm{FN}+\mathrm{TN}))$ and positive $((\mathrm{FP} /(\mathrm{FP}+\mathrm{TP}))$ errors were assessed for each model.

\section{RESULTS}

\section{In vitro assessment of drug accumulation in human AMs}

Accumulation of drugs previously investigated in $\mathrm{NR} 8383^{25}$ was assessed in freshly isolated human AMs and the data between the two in vitro systems were compared. Studies in human AMs showed over 1500-fold range in $K_{p, c e l l}$ of investigated drugs, with the most extensive accumulation seen for imipramine $\left(\mathrm{K}_{\mathrm{p}, \mathrm{cell}}=853, \mathrm{CV}\right.$ 63\%) (Table 3). Among respiratory drugs investigated, clarithromycin accumulated the most in human $\mathrm{AMs}$ with $\mathrm{K}_{\mathrm{p}, \mathrm{cell}}=115$ (mean of data from 9 individual AM donors). The inter-individual variation in clarithromycin $\mathrm{K}_{\mathrm{p}, \text { cell }}$ was $74 \%$ (Figure 2), with data ranging from 36 to 322 . The remaining respiratory drugs accumulated relatively less in human AMs $\left(\mathrm{K}_{\mathrm{p}, \text { cell }}<31\right)$. In particular, terbutaline and fenoterol intracellular concentrations remained below the extracellular medium $\left(\mathrm{K}_{\mathrm{p}, \mathrm{cell}}<1\right)$ under the conditions investigated (Table 3). Comparison of the $\mathrm{K}_{\mathrm{p}, \text { cell }}$ data between human AMs $\left(\mathrm{K}_{\mathrm{p}, \mathrm{hAM}}\right)$ and NR8383 $\left(\mathrm{K}_{\mathrm{p}, \mathrm{NR} 8383}\right)$ showed a good agreement between the two systems, with an overall bias of 2.45 -fold (gmfe). The ratio of $\mathrm{K}_{\mathrm{p}, \mathrm{NR} 8383}$ and $\mathrm{K}_{\mathrm{p}, \mathrm{hAM}}$ for 7 out of 9 drugs was within 3-fold error (Figure 3). $\mathrm{K}_{\mathrm{p}, \text { cell }}$ for clarithromycin, imipramine, terbutaline and budesonide showed a particular good agreement (within 2-fold), whereas the most pronounced outliers were fenoterol and tiotropium bromide. These two drugs had approximately 8.5 -fold higher accumulation in NR8383 relative to human AMs. 


\section{In vitro assessment of lysosomal sequestration in freshly isolated human AMs}

Among drugs studied in human AMs, clarithromycin and imipramine were selected for investigation of lysosomal sequestration using indirect method. The concentration of $\mathrm{NH}_{4} \mathrm{Cl}$ and the incubation conditions used were the same as in NR8383 to allow direct comparison between the two systems. The $\mathrm{pH}$ of incubation medium containing $\mathrm{NH}_{4} \mathrm{Cl}$ was stable through the experimental set up, as a minor reduction $(<0.05$ unit) in the $\mathrm{pH}$ was observed relative to control medium.

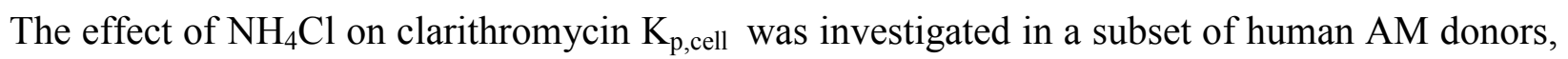
as shown in Figure 4A. The reduction in clarithromycin $\mathrm{K}_{\mathrm{p}, \text { cell }}$ in human AMs ranged from 57\% to $67 \%$ between different donors (CV 7.7\%). Overall, this reduction was not as pronounced as in the case of NR8383 (84\%, Figure 4A), suggesting higher relative contribution of lipid partitioning for clarithromycin in human AMs. Regardless of different extent of clarithromycin accumulation observed in human AMs under the control conditions (mean $\mathrm{K}_{\mathrm{p}, \text { cell }}=81, \mathrm{CV}=51 \%$ ), $\%$ reduction in $\mathrm{K}_{\mathrm{p}, \mathrm{cell}}$ in the presence of $\mathrm{NH}_{4} \mathrm{Cl}$ was comparable across donors. On average, clarithromycin accumulation in human $\mathrm{AMs}$ was reduced by $63 \%$ in the presence of $\mathrm{NH}_{4} \mathrm{Cl}$ (Table S5, Supporting Information), resulting in mean $\mathrm{K}_{\mathrm{p} \text {,cell }}$ of 32 under those conditions $(\mathrm{CV}=62 \%)$. Despite the variability in clarithromycin accumulation observed in the absence and presence of $\mathrm{NH}_{4} \mathrm{Cl}$, the $\mathrm{K}_{\mathrm{p}, \text { control }} / \mathrm{K}_{\mathrm{p}+\mathrm{NH} 4 \mathrm{Cl}}$ ratio was 2.7 on average (ranged between 2.3-3) and was consistent between $\mathrm{AM}$ donors $(\mathrm{CV}=13 \%)$.

In the case of imipramine, $\mathrm{K}_{\mathrm{p} \text {,cell }}$ was reduced by 47 to $72 \%$ across 5 human $\mathrm{AM}$ donors investigated (Figure 4B). The mean $\mathrm{K}_{\mathrm{p} \text {,cell }}$ in human $\mathrm{AMs}$ under the control and $\mathrm{NH}_{4} \mathrm{Cl}$ treatment conditions were 963 (CV 54\%) and 316 (CV 38\%), respectively. On average, the total cellular accumulation of imipramine was reduced by $62 \%(\mathrm{CV} 20 \%)$ in the presence of $\mathrm{NH}_{4} \mathrm{Cl}$ (Table S5, 
Supporting Information). The observed reduction in $\mathrm{K}_{\mathrm{p}}$ of imipramine was similar to that observed in NR8383 (Figure 4B). The $\mathrm{K}_{\mathrm{p}, \text { control }} / \mathrm{K}_{\mathrm{p}+\mathrm{NH} 4 \mathrm{Cl}}$ ratio ranged between 1.9-3.5 among AM donors, suggesting a similar magnitude of saturable process. The extent of lysosomal sequestration was the lowest for both drugs in AMs from donor 9; however, the rank order across other overlapping donors differed between clarithromycin and imipramine.

Microscopic examination of human AMs showed presence of large number of lysosomes, as evident by the localization of LTR in these organelles (Figure 5B). Treatment of human AMs with LTR by $20 \mathrm{mM} \mathrm{NH}_{4} \mathrm{Cl}$ showed a maximal reduction of $67 \%$ in the fluorescent intensity of LTR (Figure 5C). The observed effect of $\mathrm{NH}_{4} \mathrm{Cl}$ towards LTR accumulation in the lysosomes demonstrated the lysosomal targeting of this basic dye in human AMs and its accumulation by a $\mathrm{pH}$ gradient dependent mechanism. This reduction in LTR lysosomal accumulation was in agreement with the effect of $\mathrm{NH}_{4} \mathrm{Cl}$ on imipramine $\mathrm{K}_{\mathrm{p}, \text { cell }}$ in the same AM sample (Donor 6, Figure 4B). The imaging results previously reported in NR8383 cells ${ }^{25}$ were in good agreement with the current findings in human AM.

\section{In silico prediction of drug accumulation in NR8383 cells}

Using the drug and AM specific cellular parameters (Table S2, Supporting Information), the accumulation of 10 drugs previously assessed in NR8383 in vitro was predicted using the developed in silico AM models. The comparison of the predicted $\mathrm{K}_{\mathrm{p} \text {,cell }}$ by all 3 models and the $\mathrm{K}_{\mathrm{p}, \text { cell }}$ obtained in NR8383 cells is shown in Figure 6; individual predicted $\mathrm{K}_{\mathrm{p} \text {,cell }}$ and $\mathrm{K}_{\mathrm{p}}$ for other cellular model compartments (lysosomes, mitochondria and cytosol) are listed in Table S6, Supporting Information. In the case of the AM model (1), overall predictive bias was 7.8-fold (gmfe). The accumulation of basic terbutaline and formoterol and neutral budesonide was 
predicted within 3-fold of the observed data. In contrast, over-prediction of cellular accumulation was observed for basic fenoterol (3.8-fold) and permanently charged ipratropium and tiotropium bromide (>19-fold). In the case of basic clarithromycin and imipramine, the predicted $\mathrm{K}_{\mathrm{p} \text {,cell }}$ was $<10 \%$ of the observed data. For zwitterions rifampicin and ciprofloxacin, the predicted $\mathrm{K}_{\mathrm{p}, \mathrm{cell}}$ was $<1 \%$ and $\sim 14 \%$ of the observed $\mathrm{K}_{\mathrm{p}, \text { cell }}$, respectively. Use of the in silico AM model (2) reversed this under-prediction trend, resulting in reduced bias (5.7-fold) and successful prediction of the intracellular accumulation for $40 \%$ of drugs, including clarithromycin and imipramine. However, for the remaining drugs in the dataset, the $\mathrm{K}_{\mathrm{p}, \text { cell }}$ was over-predicted by this model (between $\sim 4$ to 26-fold for terbutaline and tiotropium bromide, respectively). Using the AM model (3), the accumulation of imipramine, clarithromycin, budesonide and rifampicin was predicted within 3fold of the observed data, whereas predicted $K_{p, \text { cell }}$ of ciprofloxacin was $\sim 14 \%$ of the observed data. For the remaining drugs, a general trend of over-prediction of intracellular accumulation was evident, with most pronounced over-prediction of $\mathrm{K}_{\mathrm{p} \text {,cell }}$ observed for formoterol and fenoterol. The overall predictive bias of this model (8.4-fold) was larger than that observed for the other two models.

\section{In silico prediction of lysosomal sequestration in NR8383 cells}

In addition to the prediction of $\mathrm{K}_{\mathrm{p}, \mathrm{cell}}$, the ability of the in silico models to predict the extent of lysosomal sequestration of investigated drugs in NR8383 ${ }^{25}$ was evaluated. A $30 \%$ reduction in $\mathrm{K}_{\mathrm{p}, \text { cell }}$ cut-off and categorical prediction (TP, TN, FP and FN) with probability assessment (Table S7, Supporting Information) were used to evaluate the prediction success of each of the models. Among the drugs studied, clarithromycin, imipramine and fenoterol were the three drugs for which lysosomal sequestration was correctly predicted as TP by both models (2) and (3) (Figure 
7). In contrast, model (1) significantly under-estimated the extent of lysosomal sequestration of imipramine (lysosomal $\mathrm{K}_{\mathrm{p}}$ of $38,<5 \%$ of the overall cellular accumulation). Using the $30 \%$ cutoff, the sensitivity of AM model (2) and (3) was 75\%, whereas 50\% was achieved by the model (1) (Table S7, Supporting Information). All the in silico models showed high ability to correctly assign non-lysosomotropic drugs, resulting in good specificity ( $>83 \%$ for model (2) and $67 \%$ for the other models). In the current dataset, terbutaline, rifampicin, budesonide, ipratropium and tiotropium bromide were predicted by all in silico models as non-lysosomotropic. The model predictions were inconsistent with reported $46 \%$ reduction in ipratropium bromide $\mathrm{K}_{\mathrm{p}, \text { cell }}{ }^{25}(\mathrm{FN})$; however, the physicochemical properties of this drug and the variability in the in vitro data support its non-lysosomotropic classification. Models (2) and (3) had a comparable false negative rate of $25 \%$ relative to model (1) $(50 \%)$.

The lysosomal sequestration of $80 \%$ of investigated drugs (TN and TP) was correctly predicted only by the AM model (2). This model also had the lowest incidence of false positives (10\%), resulting in the lowest PPE of 25\% (Table S7, Supporting Information). The most prominent FP was formoterol, as all 3 models predicted its substantial accumulation in lysosomes $(>80 \%)$, as opposed to $<30 \%$ observed in vitro. In the case of ciprofloxacin, only model (2) correctly predicted its non-lysosomal cellular accumulation.

\section{In silico prediction of drug accumulation and lysosomal sequestration in human AMs}

Imipramine and clarithromycin $\mathrm{K}_{\mathrm{p} \text {,cell }}$ and lysosomal $\mathrm{K}_{\mathrm{p}}$ were also predicted in human AMs (parameterized accordingly as in Table 1) due to availability of in vitro data in multiple donors for these two drugs. The intracellular accumulation of both drugs predicted by all 3 in silico AM models is shown in Figure 8. Analogous to evaluation against NR8383 data, performance of the 
AM model (1) was poor, as predicted accumulation of clarithromycin and imipramine was approximately 7 and $4 \%$ of their observed $\mathrm{K}_{\mathrm{p}, \mathrm{hAM}}$, respectively. Using the in vitro $\mathrm{K}_{\mathrm{p}+\mathrm{NH} 4 \mathrm{Cl}}$ data to account for the membrane partitioning (the AM model (2)), intracellular accumulation of both drugs was predicted within 3-fold of the observed data, with an overall bias of 1.83-fold. Furthermore, the model (2) captured successfully the variation in the observed $K_{p, c e l l}$ of clarithromycin (CV 74\%) and imipramine (CV 63\%), as the predicted $\mathrm{K}_{\mathrm{p}, \text { cell }}$ ranged between 84788 (CV 74\%) and 390-1439 (CV 48\%), respectively. In the case of the AM model (3), imipramine $K_{p, \text { cell }}$ was predicted within 3 -fold, whereas clarithromycin predicted $K_{p, \text { cell }}$ was on the borderline 3-fold error.

In addition to the $\mathrm{K}_{\mathrm{p} \text {,cell }}$ prediction, all 3 models were evaluated for their ability to predict the extent of lysosomal sequestration of both drugs in human AMs (Table 4). The predicted contribution of lysosomes to clarithromycin accumulation in human AMs ranged between 56 and $74 \%$ by the AM model (1) and (3), respectively. This was in good agreement with the observed data for clarithromycin both in individual donors (ranged between 57-67\%) and the mean data $(63 \pm 4.8 \%)$. In the case of imipramine, the model (1) significantly under-predicted the extent of its lysosomal sequestration; predicted contribution of lysosomes was $4.5 \%$ of the observed data. In contrast, the model (2) and (3) predicted the contribution of lysosomal sequestration to imipramine accumulation in human AMs as 48 and 47\%, respectively, relative to the mean observed data (62\%). 


\section{DISCUSSION}

As increased accumulation of drugs by alveolar macrophages may have important therapeutic and safety implications, it is of key interest to assess drug uptake and lysosomal sequestration of respiratory drugs in human AMs during pre-clinical development. The current study characterized the intracellular accumulation and lysosomal sequestration of a range of drugs with respiratory indication by both in vitro and in silico approaches.

\section{In vitro drug accumulation and lysosomal sequestration in human AMs}

Among respiratory drugs investigated, clarithromycin showed the most extensive accumulation in human AMs. Data obtained in AMs from multiple donors showed no clear trend between age, gender, smoking history, the time to initiate the experiments and extent of accumulation. High accumulation of clarithromycin in human AMs was previously documented in vivo where several hundred fold higher concentrations in AMs relative to plasma were reported (AM-to-plasma concentration ratios between $400-1300$ at 24 hour following the last dose $)^{47-50}$. High clarithromycin concentrations in human AMs are important for its therapeutic efficacy against intracellular bacteria resistant to biocidal mechanisms of $\mathrm{AMs}^{22}$. In contrast to clarithromycin, $\mathrm{K}_{\mathrm{p}, \text { cell }}$ remained $<1$ for a number of respiratory drugs investigated (e.g., terbutaline, fenoterol), suggesting that equilibrium between intracellular and extracellular drug concentrations was not achieved. These findings are supported by limited literature reported for hydrophilic, predominantly ionized drugs at physiological $\mathrm{pH}$, with $\mathrm{K}_{\mathrm{p}, \mathrm{hAM}}<1$ even after 60 minutes ${ }^{51}$. Although, low accumulation of these drugs in human AMs in vitro implies less likely accumulation in AMs before they interact with extracellular targets in the airways, the translation 
of present findings to the in vivo situation requires also consideration of drug formulation, particle size, physiological and disease conditions.

The paucity of in vitro drug accumulation studies in human AMs does not permit extensive comparison of the data presented here with the literature (Table S8, Supporting Information). However, it highlights more pronounced accumulation of a number of drugs in AMs from smokers. The existence of greater number of lysosomes (enlarged in some cases) containing cellular lipids in the AMs of smokers ${ }^{52-54}$ compared to non-smokers may explain increased cellular partitioning of drugs in AMs. In addition, cigarette smoke may have an effect on AM phenotype, phagocytic ability and expression of several membrane-associated proteins ${ }^{27-29,55-57}$. Analysis of lysosomal sequestration of imipramine and clarithromycin in human AMs highlighted important contribution of this process to their accumulation in AMs. The unaffected accumulation of clarithromycin and imipramine by $\mathrm{NH}_{4} \mathrm{Cl}\left(\mathrm{K}_{\mathrm{p}+\mathrm{NH} 4 \mathrm{Cl}}\right)$ can be attributed to their partitioning into membranes (plasma and organelle). While some additional unaccounted contribution of $\mathrm{pH}$ partitioning is feasible (if lysosomal $\mathrm{pH}$ did not equilibrate with cytosolic $\mathrm{pH}$ by $\mathrm{NH}_{4} \mathrm{Cl}$ ), the contribution of this process is expected to be relatively minor compared to membrane partitioning. A change in the extent of membrane partitioning (e.g., due to alteration in membrane potential in the presence of $\mathrm{NH}_{4} \mathrm{Cl}$ ) cannot be completely excluded, which would result in over- or under-estimation of the extent of lysosomal sequestration. Data for clarithromycin and imipramine here suggest minimal variation in the extent of lysosomal sequestration between individuals. However, relatively large variation in control $\mathrm{K}_{\mathrm{p} \text {,cell }}$ (assuming no transporter mediated active uptake) and $\mathrm{K}_{\mathrm{p}+\mathrm{NH} 4 \mathrm{Cl}}$ suggests potential differences in the lysosomal abundance, volume and/or the extent of membrane partitioning of both drugs between individuals, in particular in smokers, all of which may have important clinical implications. 
Potential contamination with red blood cells in the experimental set up cannot be excluded, but all efforts were made to minimize this aspect.

The extent of lysosomal accumulation of both drugs in human AMs was comparable. However, it was evident that in all AM samples in which lysosomal sequestration of both drugs was assessed, the baseline accumulation of imipramine (in the presence of $\mathrm{NH}_{4} \mathrm{Cl}$ ) was much higher compared with clarithromycin. The variability associated with clarithromycin $\mathrm{K}_{\mathrm{p}+\mathrm{NH} 4 \mathrm{Cl}}(62 \%)$ was larger relative to imipramine (38\%). These results can be rationalized by differences in lipophilicity and amphiphilicity of these drugs and their interactions with membrane acidic phospholipids. Macrolides (including clarithromycin) have been shown to bind close to the surface of dodecylphosphocholine micelles as a membrane mimetic, where predominantly electrostatic interactions between the polar lipid head groups and positively charged amino groups of macrolides occur ${ }^{58}$. In the case of imipramine, partitioning into membranes is expected to be much greater, due to both electrostatic interactions with phosphate head groups and hydrophobic interactions with the fatty acid chains in the core of the membrane bilayer ${ }^{59,60}$. While the comparison of the $\mathrm{K}_{\mathrm{p}, \mathrm{cell}}$ data from NR8383 with those from human AMs showed an overall good agreement between the two systems, the human AM data should be viewed as preliminary, highlighting the necessity for further studies. Nevertheless, the presented data provide important information regarding drug accumulation in both systems and emphasize potential of NR8383 as a surrogate in vitro tool for screening of respiratory drugs and their cellular accumulation, in particular in view of limited access to freshly isolated cells. 


\section{In silico assessment of intracellular drug accumulation and lysosomal sequestration in AMs}

In the current study the in silico AM model was developed accounting for specific cell properties of alveolar macrophages (e.g., lysosomal contribution to the cellular volume). Three subtypes of the model were considered with respect to their description of membrane partitioning of drugs and these were evaluated for predicting $\mathrm{K}_{\mathrm{p} \text {,cell }}$ and the extent of lysosomal sequestration in AMs. It was evident that the AM model (1), which assumed membrane partitioning of drugs to occur as it would in octanol, under-predicted the intracellular accumulation of a number of drugs, including clarithromycin and imipramine. In addition, the performance of this model in predicting the contribution of lysosomal sequestration to the cellular accumulation of drugs investigated was poor ( $50 \% \mathrm{FN}$ rate) (Figure 7$)$. The $30 \%$ reduction in $\mathrm{K}_{\mathrm{p} \text {,cell }}$ selected as a cut-off provided a clear distinction between the performance of three models. In the AM model (2), experimentally determined $\mathrm{K}_{\mathrm{p}+\mathrm{NH} 4 \mathrm{Cl}}$ data (when lysosomal $\mathrm{pH}$ gradient and sequestration was abolished) were used as a surrogate parameter for membrane partitioning. Overall predictive performance of this AM model was the best across in silico models investigated, with the good ability to identify lysosomotropic drugs (lowest PPE) while keeping the low NPE of $17 \%$. This in silico model showed a clear advantage to the use of simple Henderson-Hasselbalch equation which predicted high lysosomal sequestration and showed marginal distinction in the $\%$ contribution of this process to cellular accumulation of five basic drugs in the current dataset (data not shown), in contrast to the experimental observations. It is important to note that the use of $\mathrm{K}_{\mathrm{p}+\mathrm{NH} 4 \mathrm{Cl}}$ data assumed that active transport in AMs is negligible under the experimental conditions used. While this may be the case for basic drugs such as imipramine for which uptake into cell and sub-cellular compartments is likely to be driven by passive permeation, for some of the remaining drugs, the involvement of transporters has been highlighted in primary airway 
epithelial cells and OCT-transfected cells ${ }^{61-65}$. Therefore, if these transporters were present in AMs (sparse data so far in healthy and smoker subjects ${ }^{57,66}$ ), the $\mathrm{K}_{\mathrm{p}+\mathrm{NH} 4 \mathrm{Cl}}$ would also reflect the contribution of transporter-mediated active processes and may over-estimate the extent of membrane partitioning for drugs like terbutaline or formoterol.

In order to overcome the requirement for an experimentally determined data to describe drug membrane partitioning, AM model (3) was assessed; this model accounted for the fractions of neutral lipids, neutral and acidic phospholipids in AMs. Despite its mechanistic nature and promising results obtained for the prediction of membrane partitioning in hepatocytes (unpublished data), the in silico prediction of membrane partitioning resulted in a general $\mathrm{K}_{\mathrm{p}, \text { cell }}$ over-prediction (Figure 6). The reason for this trend is unclear; however, a number of factors may contribute. One important consideration is the uncertainty in the composition of lysosomal and mitochondrial membranes in AMs relative to cellular membrane. Due to lack of data it was assumed that the amount of acidic phospholipids in plasma and organelle membrane was the same. Another source of uncertainty comes from the $\mathrm{K}_{\mathrm{a}, \mathrm{BC}}$ parameter, estimated from drug $\operatorname{LogP}$, $\mathrm{pK}_{\mathrm{a}}$, blood-to-plasma partition coefficients and fraction unbound in plasma. A number of these parameters were predicted due to lack of experimental data, hence any uncertainty in the parameters would propagate to the $\mathrm{K}_{\mathrm{a}, \mathrm{BC}}$ estimates. Subsequently, any uncertainty in the AP and $\mathrm{K}_{\mathrm{a}, \mathrm{BC}}$ data would reflect in the predicted drug membrane partitioning in cell and respective compartments. One approach to reduce the prediction error would be to use measured membrane partitioning data in a system that closely resembles the composition of the cellular/tissue membrane of interest. To date, a number of mechanistic tissue distribution models have applied measured phospholipid (phosphatidylcholine):water partitioning to describe neutral phospholipid binding while calculating the acidic phospholipid partitioning from the data obtained ${ }^{67,68}$. The 
estimation of the association constant for acidic phospholipids $\left(\mathrm{K}_{\mathrm{a}, \mathrm{BC}}\right.$ as surrogate $)$ is appropriate for the basic as well as zwitterionic drugs with basic $\mathrm{pK}_{\mathrm{a}} \geq 7$ (ciprofloxacin) in the dataset ${ }^{69}$, whereas for zwitterions with basic $\mathrm{pK}_{\mathrm{a}}<7$ (rifampicin) and neutral drugs, it would be beneficial to consider also association with albumin and lipoprotein, respectively ${ }^{69}$. The goal of the current study was to develop a model which would predict primarily the extent of lysosomal sequestration of basic drugs; therefore, appropriate modifications in equations related to neutral, zwitterionic and permanently charged drugs have not been explored. The extension of the present dataset to include larger number of basic drugs and the validation of the predicted lysosomal drug concentrations in AMs with measured cell composition data are currently under investigation.

One of the key advantages of the in silico cell model developed in the current work is its ability to predict drug concentrations in the cytosol and lysosomes which are experimentally challenging to obtain. In addition, the in silico cell models presented here for AMs can be adapted to any cell type by modifying the system specific input parameters (volume, membrane electrical potential, $\mathrm{pH}$ ). This is particularly important for identifying compounds with tendency to accumulate in lysosome-rich tissues such as lungs, liver and kidneys and to what extent this process may affect drug efficacy or potential adverse effects (e.g., phospholipidosis). Furthermore, the presented in silico cell models provide a basis for investigation of untested scenarios and improved understanding of the impact of changes in $\mathrm{pH}$ gradient and in cell morphology (due to environmental factors, disease) on drug intracellular and/or intra-organelle concentration. A number of processes including the possible changes in lysosomal volume, membrane potential and permeability by the accumulated drug, potential transporter-mediated uptake/efflux and membrane internalization by endocytosis can be considered for further 
development of the in silico model when appropriate supporting data become available. In silico cell models that are applicable to many different cell types and have the ability to account for both system and drug properties are valuable in facilitating compound selection in drug discovery and to guide experimental design. Likewise, the in vitro generated data are used to evaluate the performance of these models and inform further refinement.

In conclusion, the cellular accumulation of a wide range of respiratory drugs was investigated in human AMs for the first time. In addition, lysosomal sequestration of basic drugs and its interdonor variability was elucidated using clarithromycin and imipramine as representative examples. The preliminary results from the current study highlighted an overall good agreement in the extent of cellular accumulation between human AMs and NR8383 cells, although differences were evident in the partitioning to acidic phospholipids. The in silico mechanistic model was developed for AMs with the aim to predict intracellular and intra-organelle drug concentrations, including lysosomes. At present, the model performs the best when experimental $\mathrm{K}_{\mathrm{p}+\mathrm{NH} 4 \mathrm{Cl}}$ data are used as input parameter for membrane partitioning, highlighting the gaps in existing cellular data (e.g., membrane composition). The current experimental approach combined with modeling represents a novel strategy in predicting cellular and lysosomal drug concentrations. 


\section{Acknowledgements}

A.U. was supported by a PhD studentship from the Biotechnology and Biological Sciences Research Council, UK (BB/1532488/1) and GlaxoSmithKline, Stevenage, UK. The authors acknowledge Sue Murby and Dr David Hallifax (University of Manchester) for assistance with the analytical assays and useful discussions on data analysis, Dr Alain Pluen (University of Manchester) for his assistance with confocal imaging and Dr Peter Eddershaw (GlaxoSmithKline) for his support and useful discussions. Part of this work was presented at the $13^{\text {th }}$ European ISSX Meeting in Glasgow, UK, June 22 - 25, 2015.

\section{Author contributions}

AU conducted the experiments, performed data analysis, contributed to the implementation of the in silico cell model and wrote the manuscript. FA and LG contributed to the validation of the in silico model, collation of literature data and writing of the manuscript. JP provided human alveolar macrophages and patient ethical approval. VD and MG supported the development of the in silico cell model. JBH and AG contributed to the research study design and writing of the manuscript.

\section{Conflict of Interest}

The authors declare no conflict of interest 


\section{Figure Legends}

Figure 1. The cell model scheme demonstrates the processes involved in the uptake of a weak base into the cell and sub-cellular compartments. The figure was adapted from Trapp et al. $(2008)^{16}$

Figure 2. Variation in clarithromycin cell-to-media concentration ratio $\left(\mathrm{K}_{\mathrm{p}, \mathrm{cell}}\right)$ in human alveolar macrophages (AMs) from 9 individual donors. (口) Male; ( $\square$ ) Female. Numbers below bars indicate donor number. The third value was obtained from pooled AMs from 2 males. The $\mathrm{K}_{\mathrm{p} \text {,cell }}$ was determined using mean clarithromycin media concentration for AMs from donors 1, 2 and 6.

Figure 3. Correlation of the cell-to-unbound medium concentration ratio $\left(\mathrm{K}_{\mathrm{p}, \mathrm{cell}}\right)$ between human alveolar macrophages (AMs) and NR8383 cells. Solid line represents the line of unity and dashed lines represent 3-fold deviation from the line of unity. Error bars indicate the standard deviation. ( $\square$ ) imipramine; (๑) clarithromycin; ( $\star$ ) budesonide; $(\diamond)$ rifampicin; ( $\Delta$ ) formoterol; (中) ipratropium bromide; ( $\boldsymbol{\nabla})$ tiotropium bromide; $(*)$ fenoterol; $(\times)$ terbutaline. Data for NR8383 are from Ufuk et al. $(2015)^{25}$.

Figure 4. Cell-to-unbound medium concentration ratio $\left(K_{p, c e l l}\right)$ of $(A)$ clarithromycin and (B) imipramine in human alveolar macrophages and NR8383 in the absence ( $\square$ ) and presence ( $\square$ ) of $20 \mathrm{mM} \mathrm{NH}{ }_{4} \mathrm{Cl}$. Data in human AMs represent single measurements in individual human AM donors, whereas in NR8383, data represent mean \pm SD of 3 separate experiments ${ }^{25}$. Numbers above bars indicate $\%$ reduction in $\mathrm{K}_{\mathrm{p}, \text { cell }}$ due to $\mathrm{NH}_{4} \mathrm{Cl}$ treatment (**, $\mathrm{p}<0.01$ by t-test).

Figure 5. Confocal microscopic images of human alveolar macrophages treated with LysoTracker Red (LTR) in the absence and presence of $\mathrm{NH}_{4} \mathrm{Cl}$. (A) A contrast image of human AMs treated with $200 \mathrm{nM}$ LTR; (B) the same cells being excited to detect LTR localized in 
lysosomes under control conditions; (C) the localization of LTR in the lysosomes of human AMs was reduced in the presence of $20 \mathrm{mM} \mathrm{NH}_{4} \mathrm{Cl}$.

Figure 6. Comparison of observed and predicted $\mathrm{K}_{\mathrm{p}, \text { cell }}$ of drugs in NR8383. Solid and dashed lines represent the line of unity and 3-fold prediction error, respectively. Black, red and blue symbols represent predictions with the AM model (1), (2) and (3), respectively. ( $\square$ ) imipramine; (○) clarithromycin; ( $\downarrow$ ) budesonide; $(\phi)$ ciprofloxacin; $(\diamond)$ rifampicin; $(\triangle)$ formoterol; ( ipratropium bromide; $(\nabla)$ tiotropium bromide; $(*)$ fenoterol; $(\times)$ terbutaline.

Figure 7. Comparison of observed and predicted \% contribution of lysosomal sequestration to cellular accumulation of drugs in alveolar macrophages (AM). Solid lines represent 30\% categorical cut-off to indicate true positive (TP), true negative (TN), false positive (FP) and false negative (FN) data. Black, red and blue symbols represent predictions with the AM model (1), (2) and (3), respectively. ( $\square$ ) represents imipramine; (O) clarithromycin; ( $\downarrow)$ budesonide; ( $\phi$ ) ciprofloxacin; $(\diamond)$ rifampicin; $(\triangle)$ formoterol; ( 虫) ipratropium bromide; $(\nabla)$ tiotropium bromide; (*) fenoterol and $(\times)$ terbutaline.

Figure 8. Comparison of observed and predicted $\mathrm{K}_{\mathrm{p}, \mathrm{cell}}$ of drugs in human alveolar macrophages (AMs). Solid and dashed lines represent the line of unity and 3-fold prediction error, respectively. Black, red and blue symbols represent predictions with the AM model (1), (2) and (3), respectively. $\mathrm{K}_{\mathrm{p}+\mathrm{NH} 4 \mathrm{Cl}}$ data were used to predict $\mathrm{K}_{\mathrm{p}, \text { cell }}$ in individual human AM donors using in silico AM model (2). ( $\square$ ) represents imipramine and (O) clarithromycin. 


\section{Figures}

Fig. 1

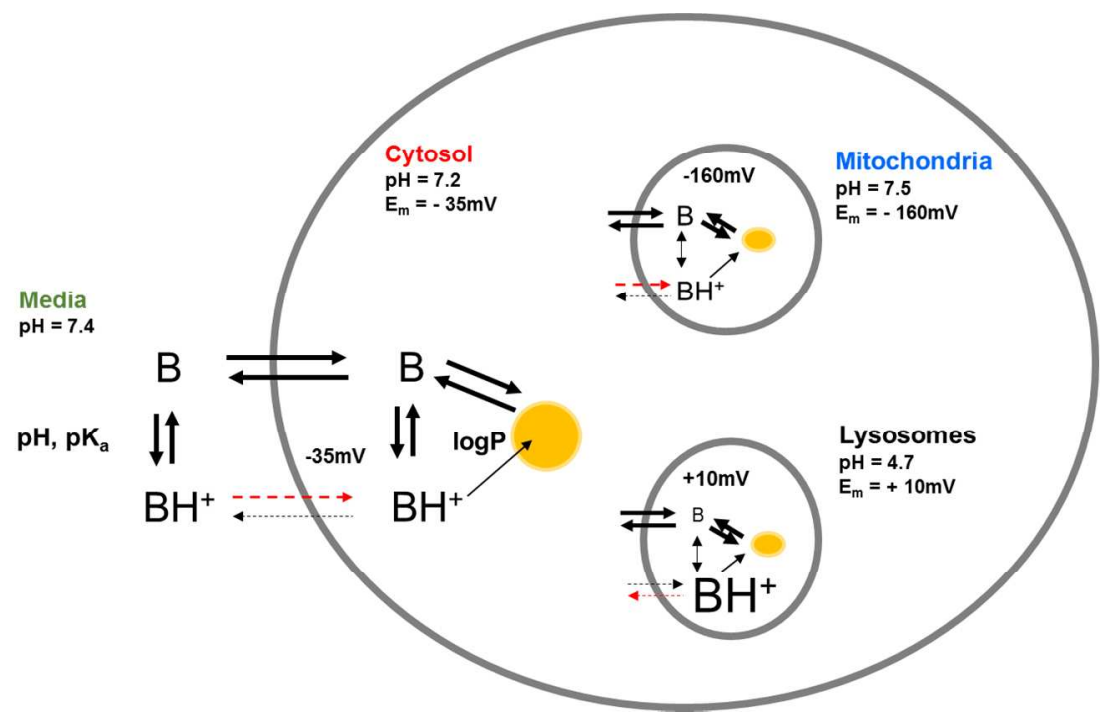

Fig. 2

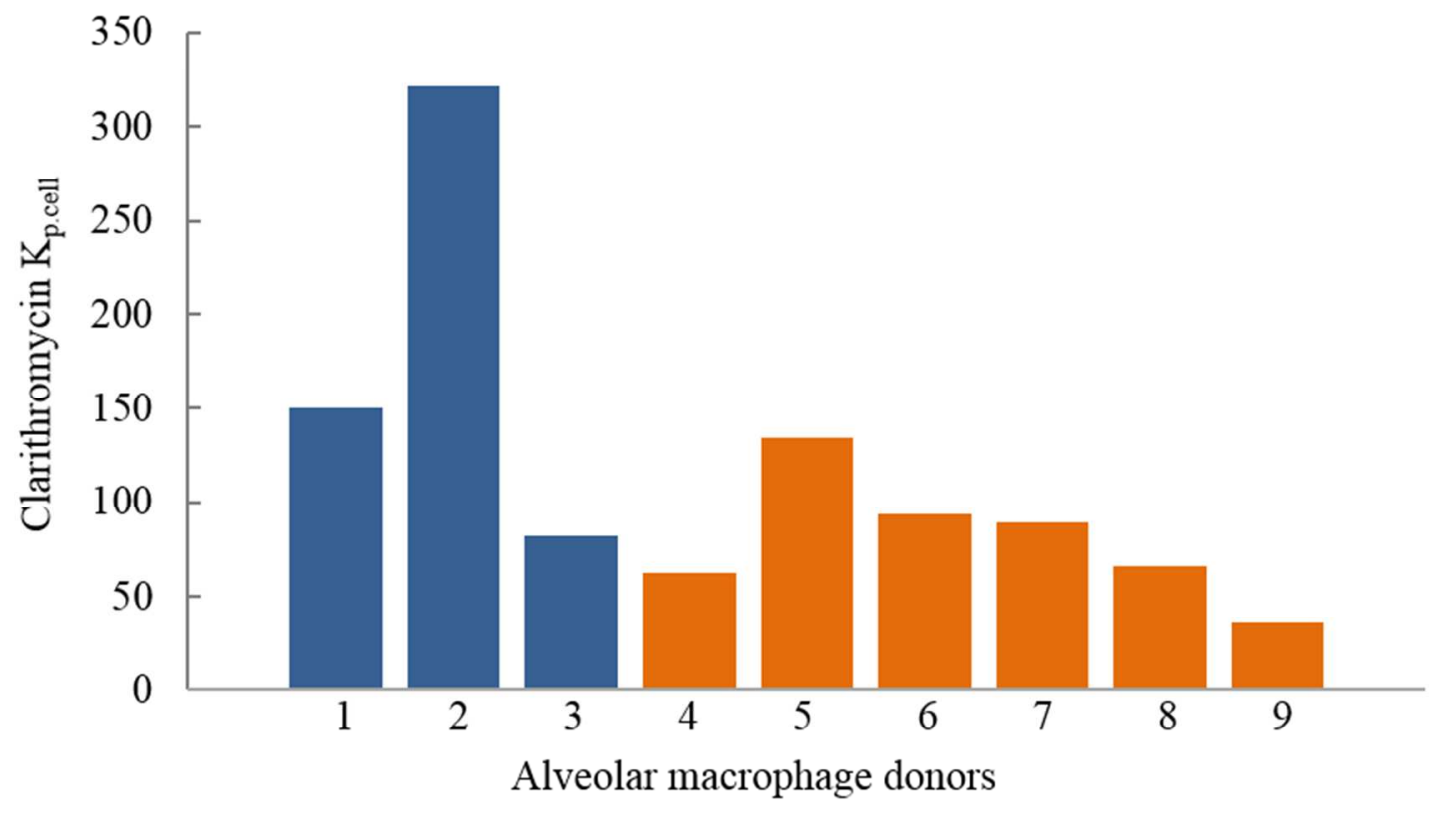

ACS Paragon Plus Environment 
Fig. 3

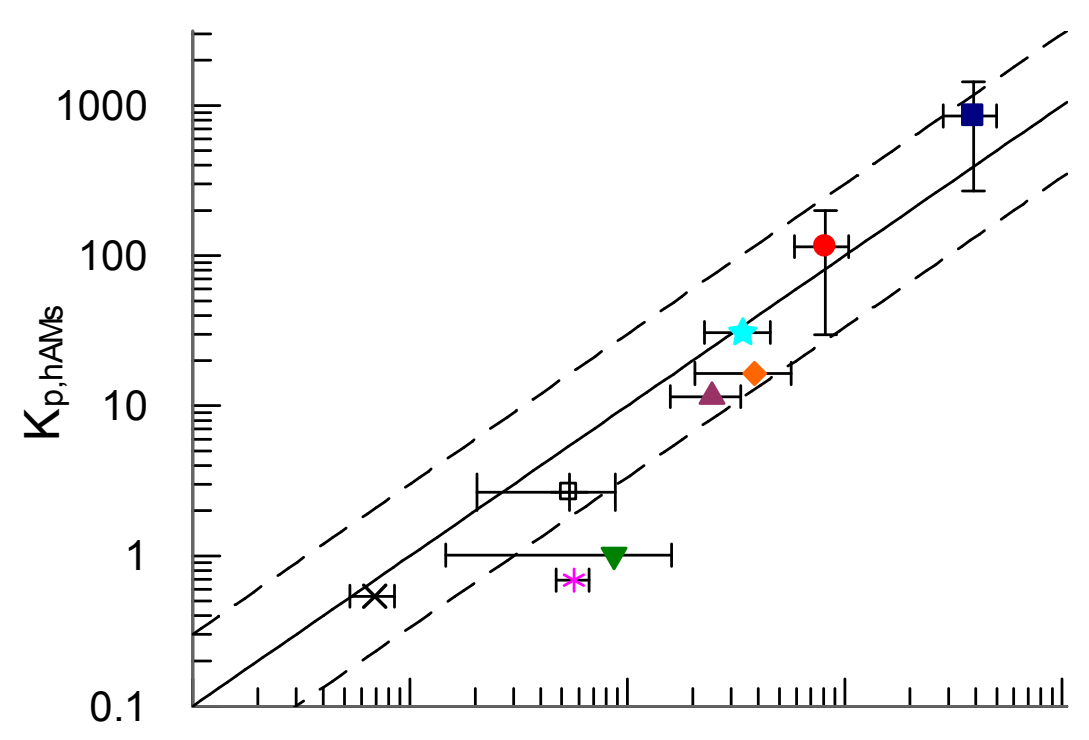

$K_{p, N R 8383}$

Fig. 4

A

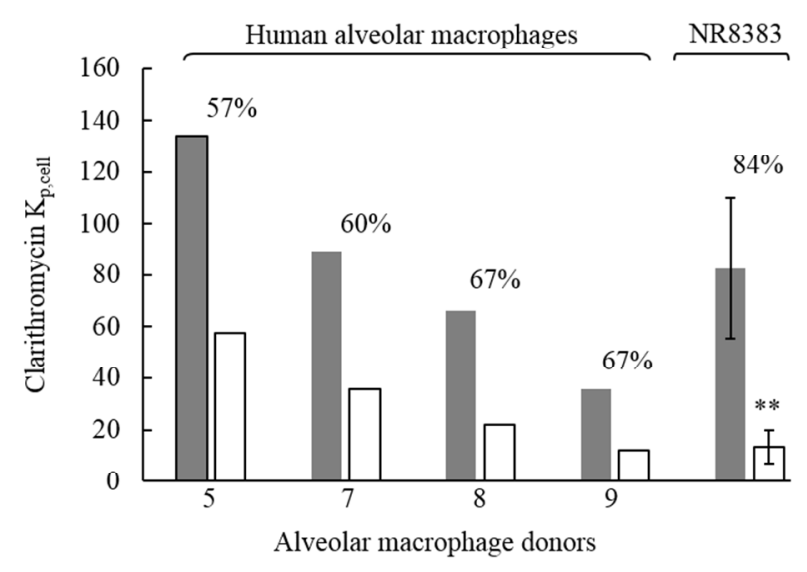

B

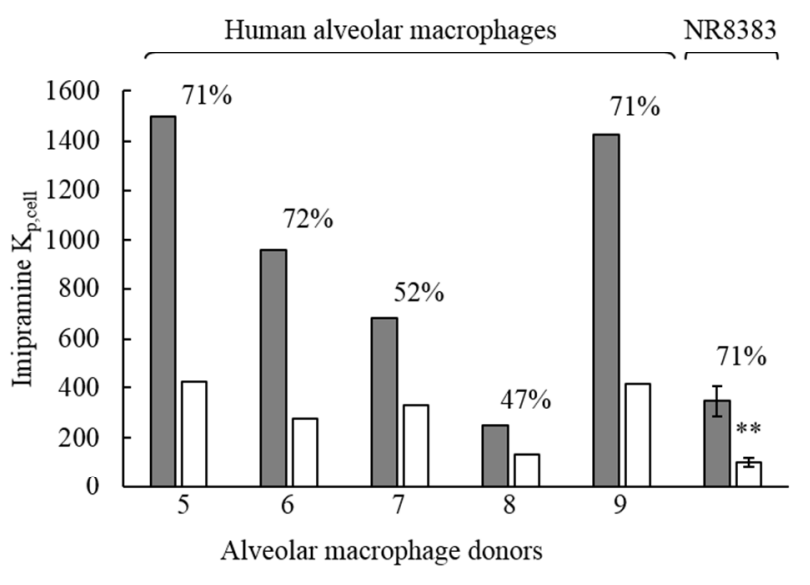


Fig. 5

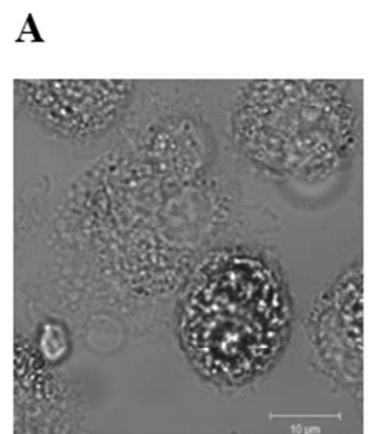

$$
\text { Human AMs }
$$

B

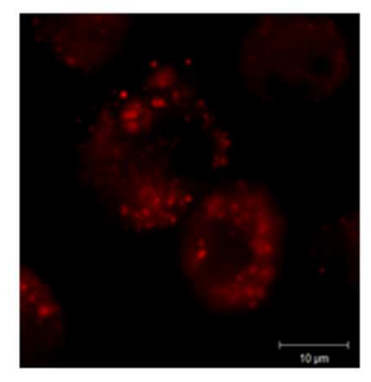

+ LysoTracker Red

(Control)
C

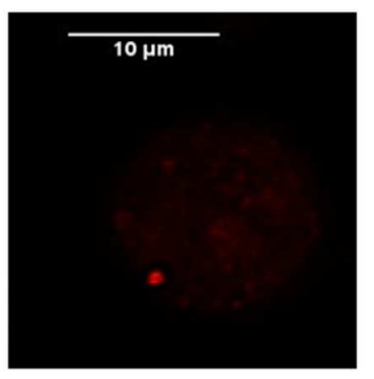

$+\mathrm{NH}_{4} \mathrm{Cl}$

Fig. 6

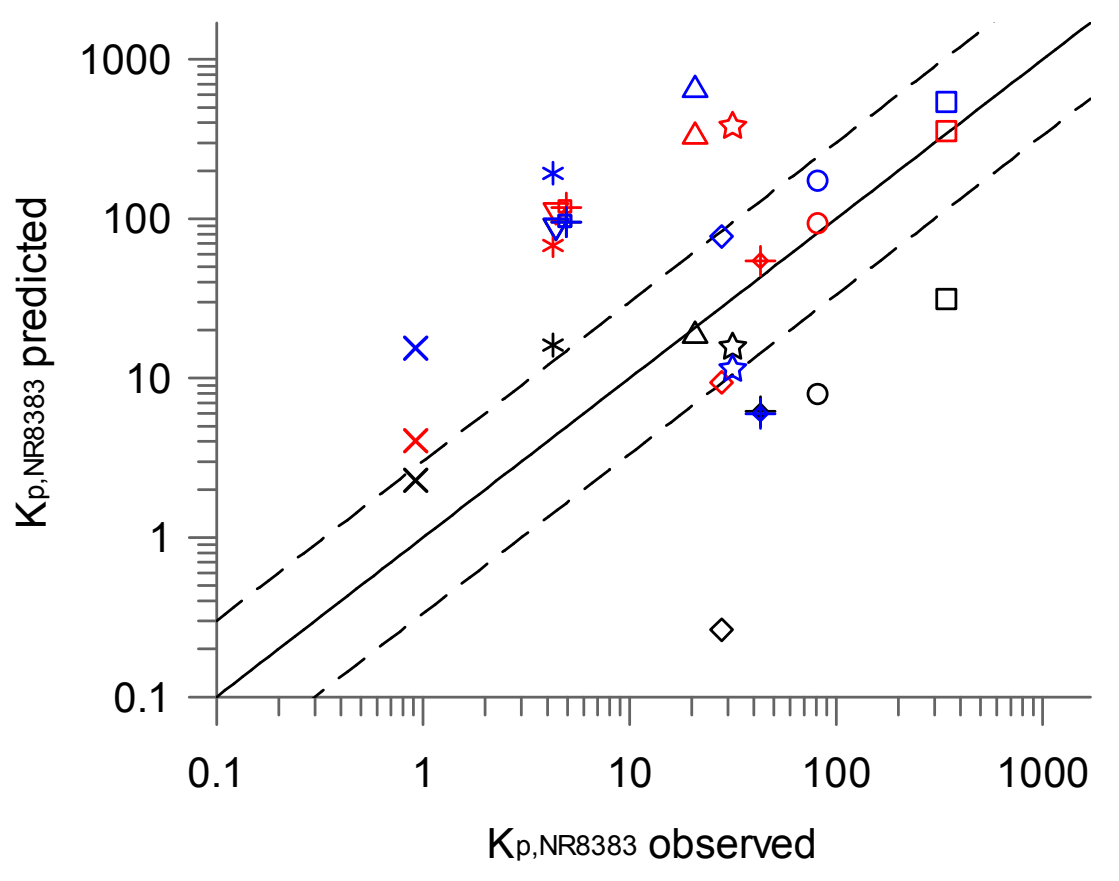

ACS Paragon Plus Environment 
Fig. 7

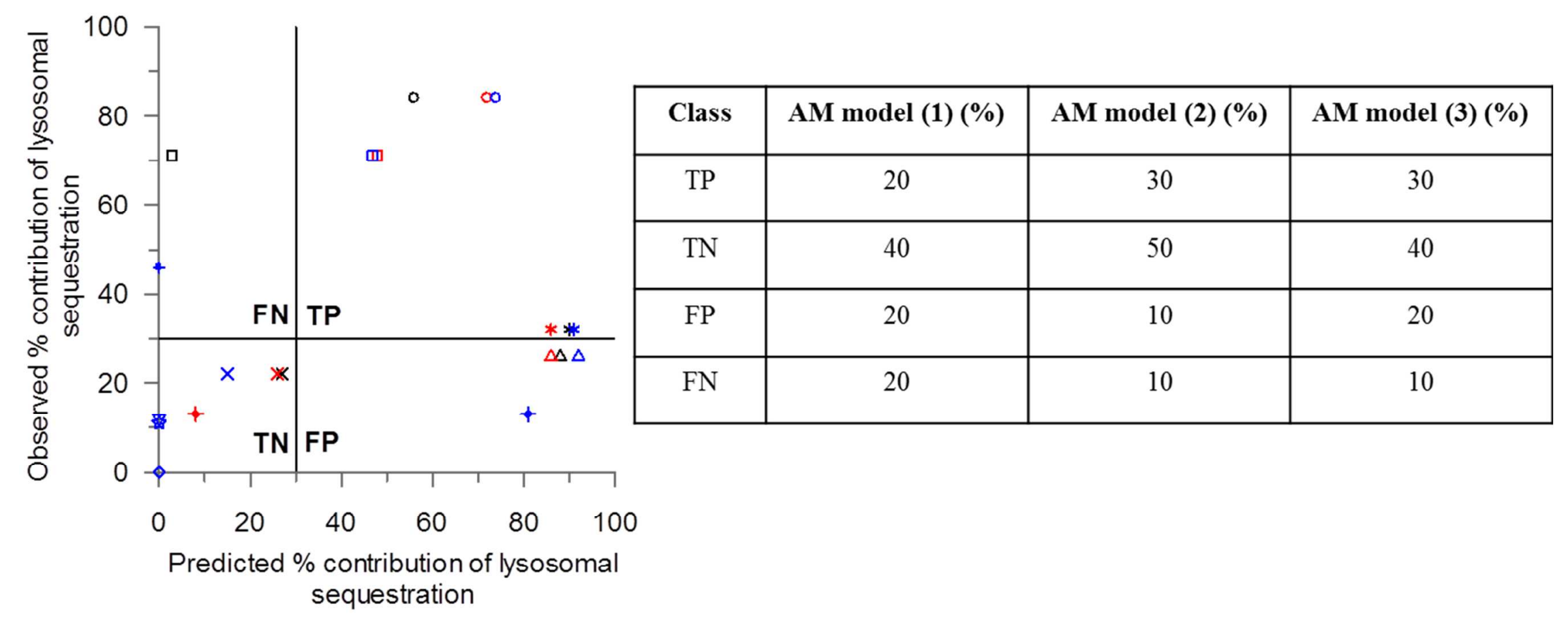


Fig. 8

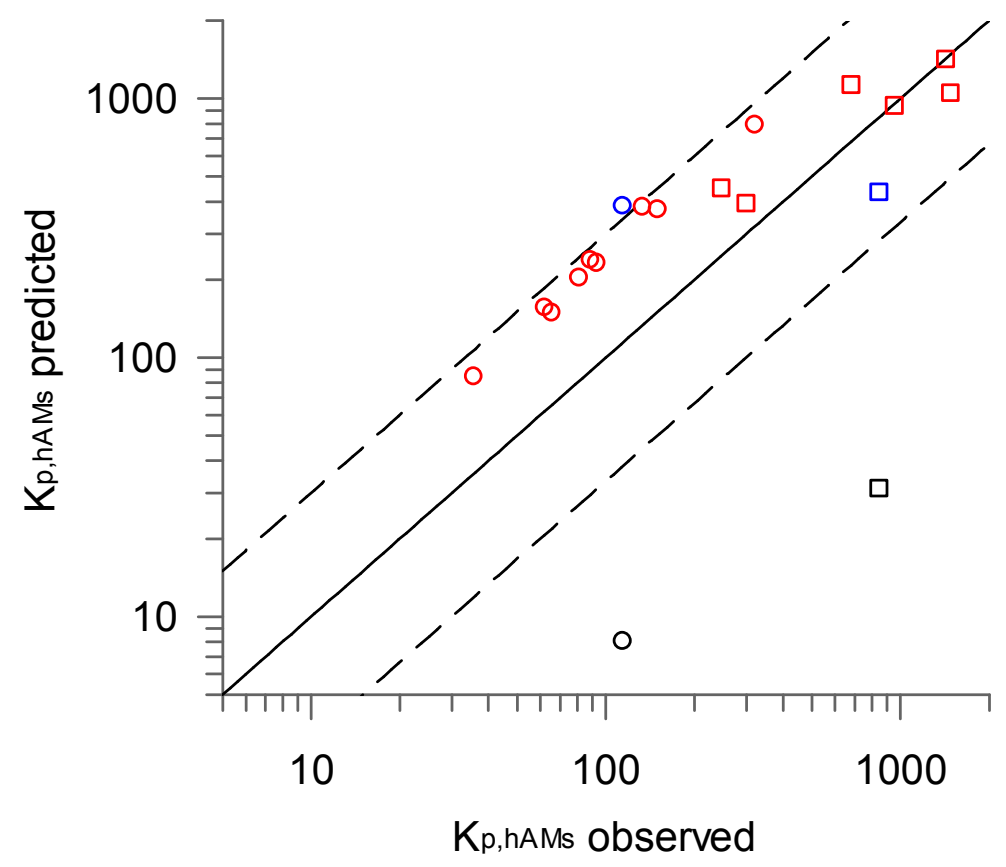

\section{TOC Graphic}

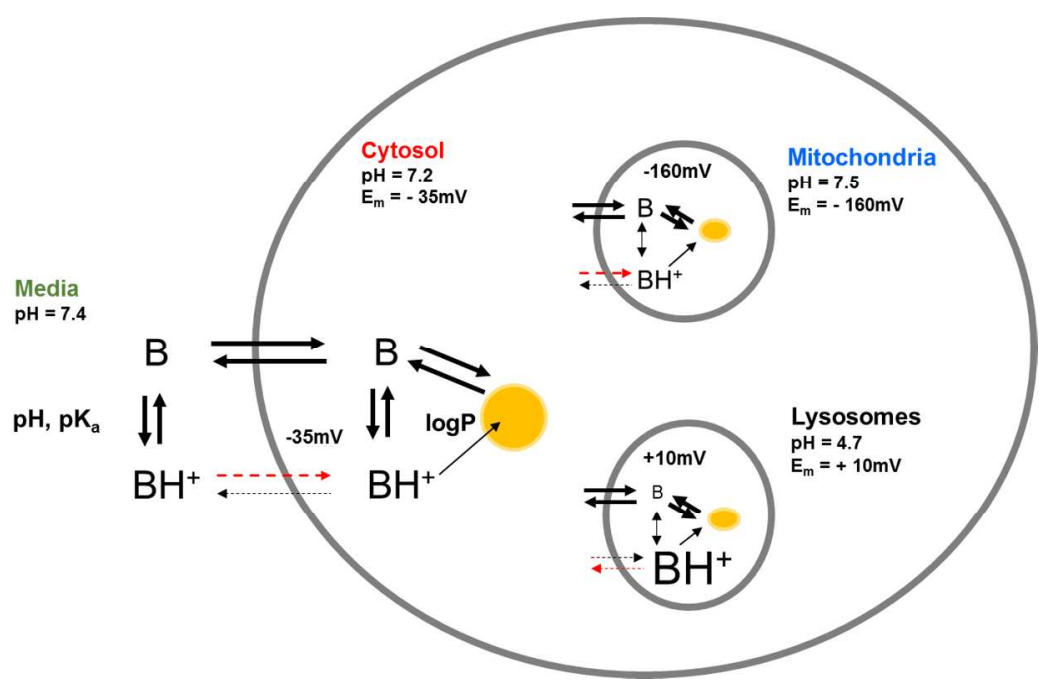

ACS Paragon Plus Environment 


\section{Tables}

Table 1. Human alveolar macrophage parameters used as input for the in silico mechanistic cell model

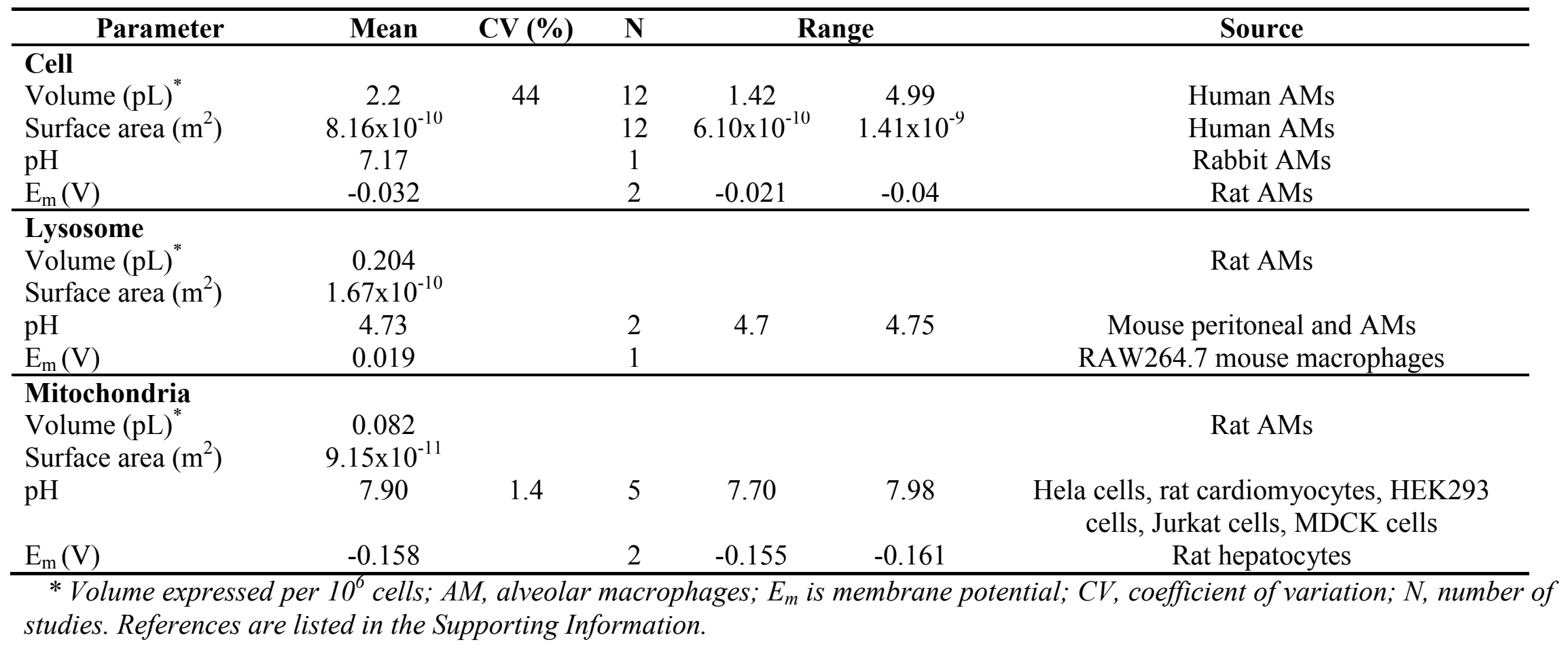


Table 2. Parameterization of the three in silico AM models in terms of membrane partitioning

\begin{tabular}{|c|c|c|}
\hline & Membrane partitioning & Description \\
\hline AM model (1) & $K_{p}=L \times\left(K_{o w}+K_{o w, D}\right)=L \times\left(10^{\log P}+10^{\log P+3.5}\right)$ & $\begin{array}{l}\text { Octanol-water partitioning used as a } \\
\text { surrogate. For partitioning of the } \\
\text { ionized species, a penalty of } 3.5 \log \mathrm{P} \\
\text { units was applied. }\end{array}$ \\
\hline AM model (2) & $K_{p}=K_{p+N H 4 C l}$ & $\begin{array}{l}\text { Experimental } \mathrm{K}_{\mathrm{p}+\mathrm{NH} 4 \mathrm{Cl}} \text { data used to } \\
\text { account for partitioning of drugs into } \\
\text { biological membranes (including also } \\
\text { acidic phospholipids) }\end{array}$ \\
\hline AM model (3) & $\begin{array}{r}K_{p}=\left(\frac{1+10^{p K_{a}-p H_{\text {in }}}}{1+10^{p K_{a}-p H_{\text {out }}}} \times W\right)+\left(\frac{K_{a} \times[A P] \times 10^{p K_{a}-p H_{\text {in }}}}{1+10^{p K_{a}-p H_{\text {out }}}}\right) \\
+\left(\frac{\left(K_{\text {ow }} \times f_{N L}+\left(\left(0.3 \times K_{\text {ow }}+0.7\right) \times f_{N P}\right)\right)}{1+10^{p K_{a}-p H_{\text {out }}}}\right)\end{array}$ & $\begin{array}{l}\text { Predicted membrane partitioning using } \\
\text { Rodgers \& Rowland model }{ }^{1} \text { and } \\
\text { accounting for partitioning of drugs into } \\
\text { neutral lipids as well as neutral and } \\
\text { acidic phospholipids }\end{array}$ \\
\hline
\end{tabular}

$K_{p}$, cell-to-unbound medium concentration ratio; $W$ and L,water and lipid fractions, respectively; $K_{\text {ow }}$ and $K_{\text {ow,D, }}$ octanol-water partition coefficient for neutral and dissociated (ionized) drugs, respectively; $K_{p+N H 4 C l}, K_{p}$ in the presence of $\mathrm{NH}_{4} \mathrm{Cl}$; $p H_{\text {in }}$ and $p H_{\text {out }}$ pH of intracellular compartments and medium, respectively; AP, acidic phospholipids, $f_{N L}$ and $f_{N P}$ are the fraction of neutral lipids and neutral phospholipids, respectively 
Table 3. Cell-to-unbound medium concentration ratio of 9 drugs in human alveolar macrophages $\left(\mathrm{K}_{\mathrm{p}, \mathrm{hAM}}\right)$. Data are from a single experiment for all drugs except for clarithromycin and imipramine for which data represent mean \pm SD from multiple donors.

\begin{tabular}{|c|c|c|c|c|c|}
\hline Drug & $\log P$ & $\mathbf{p K}_{\mathbf{a} \_\mathbf{b}}$ & $\mathbf{p K}_{\mathbf{a} \_\mathbf{a}}$ & Acid-base property & $\mathbf{K}_{\mathrm{p}, \mathrm{AMs}}$ \\
\hline Imipramine & 4.8 & 9.50 & & Base & $853 \pm 583$ \\
\hline Clarithromycin & 3.16 & 8.99 & & Base & $115 \pm 85.2$ \\
\hline Formoterol & 1.99 & 8.14 & $10.1,11.8$ & Base & $11.5^{*}$ \\
\hline Budesonide & 2.47 & & & Neutral & 30.8 \\
\hline Rifampicin & 2.54 & 6.70 & 1.70 & Zwitterion & $16.4^{*}$ \\
\hline Tiotropium bromide & -1.23 & & & Permanently cationic & 1.01 \\
\hline Fenoterol & 1.09 & 8.25 & $9.40,10.1$ & Base & 0.69 \\
\hline Ipratropium bromide & -1.20 & & & Permanently cationic & 2.65 \\
\hline Terbutaline & 0.90 & 9.90 & $8.60,11.0$ & Base & 0.54 \\
\hline
\end{tabular}

References for the physicochemical properties of investigated drugs are listed in the previous study ${ }^{25} ; *$ Nominal media concentration were used in the estimation of $K_{p, c e l l}$ 
Table 4. Predicted contribution of lysosomes in imipramine and clarithromycin accumulation in human alveolar macrophages using in silico AM model (1), (2) and (3), and comparison to the observed data (individual donors and the mean \pm standard deviation)

\begin{tabular}{|c|c|c|c|c|c|c|c|}
\hline & & \multicolumn{6}{|c|}{ \% Contribution of lysosomes in accumulation in human alveolar macrophage } \\
\hline & & Donor 5 & Donor 6 & Donor 7 & Donor 8 & Donor 9 & Mean \pm SD \\
\hline \multirow[t]{4}{*}{ Clarithromycin } & Observed & 57 & $\mathrm{n} / \mathrm{a}^{*}$ & 60 & 67 & 67 & $63 \pm 4.8$ \\
\hline & Predicted- AM model (1) & & & 56 & & & \\
\hline & Predicted- AM model (2) & 71 & & 71 & 71 & 72 & \\
\hline & Predicted- AM model (3) & & & 74 & & & \\
\hline \multirow[t]{4}{*}{ Imipramine } & Observed & 72 & 71 & 52 & 47 & 71 & $62 \pm 12$ \\
\hline & Predicted- AM model (1) & & & 3 & & & \\
\hline & Predicted- AM model (2) & 48 & 48 & 48 & 48 & 48 & \\
\hline & Predicted- AM model (3) & & & 47 & & & \\
\hline
\end{tabular}




\section{References}

1. Rodgers, T.; Leahy, D.; Rowland, M. Physiologically based pharmacokinetic modeling 1: predicting the tissue distribution of moderate-to-strong bases. J Pharm Sci 2005, 94, (6), 125976.

2. Reasor, M. J.; Hastings, K. L.; Ulrich, R. G. Drug-induced phospholipidosis: issues and future directions. Expert Opin Drug Saf 2006, 5, (4), 567-83.

3. Duvvuri, M.; Krise, J. P. A novel assay reveals that weakly basic model compounds concentrate in lysosomes to an extent greater than $\mathrm{pH}$-partitioning theory would predict. Mol Pharm 2005, 2, (6), 440-8.

4. Chen, V. Y.; Rosania, G. R. The great multidrug-resistance paradox. ACS Chem Biol 2006, 1, (5), 271-3.

5. Logan, R.; Funk, R. S.; Axcell, E.; Krise, J. P. Drug-drug interactions involving lysosomes: mechanisms and potential clinical implications. Expert Opin Drug Metab Toxicol 2012, 8, (8), 943-58.

6. Logan, R.; Kong, A.; Krise, J. P. Evaluating the roles of autophagy and lysosomal trafficking defects in intracellular distribution-based drug-drug interactions involving lysosomes. J Pharm Sci 2013, 102, (11), 4173-80.

7. Daniel, W. A.; Wojcikowski, J. Lysosomal trapping as an important mechanism involved in the cellular distribution of perazine and in pharmacokinetic interaction with antidepressants. Eur Neuropsychopharmacol 1999, 9, (6), 483-91.

8. Bäckström, E.; Boger, E.; Lundqvist, A.; Hammarlund-Udenaes, M.; Friden, M. Lung Retention by Lysosomal Trapping of Inhaled Drugs Can Be Predicted In Vitro With Lung Slices. J Pharm Sci 2016, 105, (11), 3432-3439.

9. Chu, X.; Korzekwa, K.; Elsby, R.; Fenner, K.; Galetin, A.; Lai, Y.; Matsson, P.; Moss, A.; Nagar, S.; Rosania, G. R.; Bai, J. P.; Polli, J. W.; Sugiyama, Y.; Brouwer, K. L. Intracellular drug concentrations and transporters: measurement, modeling, and implications for the liver. Clin Pharmacol Ther 2013, 94, (1), 126-41.

10. Zhang, X.; Shedden, K.; Rosania, G. R. A cell-based molecular transport simulator for pharmacokinetic prediction and cheminformatic exploration. Mol Pharm 2006, 3, (6), 704-16.

11. Friden, M.; Bergstrom, F.; Wan, H.; Rehngren, M.; Ahlin, G.; Hammarlund-Udenaes, M.; Bredberg, U. Measurement of unbound drug exposure in brain: modeling of $\mathrm{pH}$ partitioning explains diverging results between the brain slice and brain homogenate methods. Drug Metab Dispos 2011, 39, (3), 353-62.

12. Ménochet, K.; Kenworthy, K. E.; Houston, J. B.; Galetin, A. Simultaneous assessment of uptake and metabolism in rat hepatocytes: a comprehensive mechanistic model. $J$ Pharmacol Exp Ther 2012, 341, (1), 2-15.

13. Nagar, S.; Tucker, J.; Weiskircher, E. A.; Bhoopathy, S.; Hidalgo, I. J.; Korzekwa, K. Compartmental models for apical efflux by P-glycoprotein--part 1: evaluation of model complexity. Pharm Res 2014, 31, (2), 347-59.

14. Ghosh, A.; Maurer, T. S.; Litchfield, J.; Varma, M. V.; Rotter, C.; Scialis, R.; Feng, B.; Tu, M.; Guimaraes, C. R.; Scott, D. O. Toward a unified model of passive drug permeation II: the physiochemical determinants of unbound tissue distribution with applications to the design of hepatoselective glucokinase activators. Drug Metab Dispos 2014, 42, (10), 1599-610.

15. Korzekwa, K. R.; Nagar, S.; Tucker, J.; Weiskircher, E. A.; Bhoopathy, S.; Hidalgo, I. J. Models to predict unbound intracellular drug concentrations in the presence of transporters. Drug Metab Dispos 2012, 40, (5), 865-76. 
16. Trapp, S.; Rosania, G. R.; Horobin, R. W.; Kornhuber, J. Quantitative modeling of selective lysosomal targeting for drug design. Eur Biophys $J$ 2008, 37, (8), 1317-28.

17. Trapp, S.; Horobin, R. W. A predictive model for the selective accumulation of chemicals in tumor cells. Eur Biophys J 2005, 34, (7), 959-66.

18. Hallifax, D.; Houston, J. B. Saturable uptake of lipophilic amine drugs into isolated hepatocytes: mechanisms and consequences for quantitative clearance prediction. Drug Metab Dispos 2007, 35, (8), 1325-32.

19. Heyneman, C. A.; Reasor, M. J. Role of the alveolar macrophage in the induction of pulmonary phospholipidosis by chlorphentermine. II. Drug uptake into cells in vitro. $J$ Pharmacol Exp Ther 1986, 236, (1), 60-4.

20. Antonini, J. M.; Reasor, M. J. Accumulation of amiodarone and desethylamiodarone by rat alveolar macrophages in cell culture. Biochem Pharmacol 1991, 42, (Supplement 1), S151S156.

21. Togami, K.; Chono, S.; Morimoto, K. Distribution characteristics of clarithromycin and azithromycin, macrolide antimicrobial agents used for treatment of respiratory infections, in lung epithelial lining fluid and alveolar macrophages. Biopharm Drug Dispos 2011, 32, (7), 389-97.

22. Togami, K.; Chono, S.; Morimoto, K. Subcellular Distribution of Azithromycin and Clarithromycin in Rat Alveolar Macrophages (NR8383) in Vitro. Biol Pharm Bull 2013, 36, (9), 1494-9.

23. Togami, K.; Chono, S.; Seki, T.; Morimoto, K. Distribution characteristics of telithromycin, a novel ketolide antimicrobial agent applied for treatment of respiratory infection, in lung epithelial lining fluid and alveolar macrophages. Drug Metab Pharmacokinet 2009, 24, (5), 411-7.

24. Togami, K.; Chono, S.; Seki, T.; Morimoto, K. Intracellular pharmacokinetics of telithromycin, a ketolide antibiotic, in alveolar macrophages. J Pharm Pharmacol 2010, 62, (1), $71-5$.

25. Ufuk, A.; Somers, G.; Houston, J. B.; Galetin, A. In Vitro Assessment of Uptake and Lysosomal Sequestration of Respiratory Drugs in Alveolar Macrophage Cell Line NR8383. Pharm Res 2015, 32, (12), 3937-51.

26. Nadanaciva, S.; Lu, S.; Gebhard, D. F.; Jessen, B. A.; Pennie, W. D.; Will, Y. A high content screening assay for identifying lysosomotropic compounds. Toxicology in vitro : an international journal published in association with BIBRA 2011, 25, (3), 715-23.

27. Higham, A.; Booth, G.; Lea, S.; Southworth, T.; Plumb, J.; Singh, D. The effects of corticosteroids on COPD lung macrophages: a pooled analysis. Respir Res 2015, 16, 98.

28. Southworth, T.; Metryka, A.; Lea, S.; Farrow, S.; Plumb, J.; Singh, D. IFN-gamma synergistically enhances LPS signalling in alveolar macrophages from COPD patients and controls by corticosteroid-resistant STAT1 activation. Br J Pharmacol 2012, 166, (7), 2070-83.

29. Plumb, J.; Robinson, L.; Lea, S.; Banyard, A.; Blaikley, J.; Ray, D.; Bizzi, A.; Volpi, G.; Facchinetti, F.; Singh, D. Evaluation of glucocorticoid receptor function in COPD lung macrophages using beclomethasone-17-monopropionate. PloS one 2013, 8, (5), e64257.

30. Hallifax, D.; Houston, J. B. Uptake and intracellular binding of lipophilic amine drugs by isolated rat hepatocytes and implications for prediction of in vivo metabolic clearance. Drug Metab Dispos 2006, 34, (11), 1829-36.

31. Yabe, Y.; Galetin, A.; Houston, J. B. Kinetic characterization of Rat Hepatic Uptake of 16 Actively Transported Drugs. Drug Metab Dispos 2011. 
32. Harris, J. O.; Swenson, E. W.; Johnson, J. E., 3rd. Human alveolar macrophages: comparison of phagocytic ability, glucose utilization, and ultrastructure in smokers and nonsmokers. J Clin Invest 1970, 49, (11), 2086-96.

33. Reynolds, H. Y.; Newball, H. H. Analysis of proteins and respiratory cells obtained from human lungs by bronchial lavage. J Lab Clin Med 1974, 84, (4), 559-73.

34. Territo, M. C.; Golde, D. W. The function of human alveolar macrophages. $J$ Reticuloendothel Soc 1979, 25, (1), 111-20.

35. Pauletti, M.; Wunderli-Allenspach, H. Partition coefficients in vitro: artificial membranes as a standardized distribution model. European Journal of Pharmaceutical Sciences 1994, $1,(5), 273$ - 282.

36. Austin, R. P.; Davis, A. M.; Manners, C. N. Partitioning of ionizing molecules between aqueous buffers and phospholipid vesicles. J Pharm Sci 1995, 84, (10), 1180-3.

37. Krämer, S. D.; Wunderli-Allenspach, H. The pH-dependence in the partitioning behaviour of (RS)-[3H]propranolol between MDCK cell lipid vesicles and buffer. Pharm Res 1996, 13, (12), 1851-5.

38. Ottiger, C.; Wunerli-Allenspach, H. Partition behaviour of acids and bases in a phosphatidylcholine liposome-buffer equilibrium dialysis system. European Journal of Pharmaceutical Sciences 1997, 5, (4), 223 - 231.

39. Avdeef, A.; Box, K. J.; Comer, J. E.; Hibbert, C.; Tam, K. Y. pH-metric $\operatorname{logP} 10$. Determination of liposomal membrane-water partition coefficients of ionizable drugs. Pharm Res 1998, 15, (2), 209-15.

40. Fruttero, R.; Caron, G.; Fornatto, E.; Boschi, D.; Ermondi, G.; Gasco, A.; Carrupt, P. A.; Testa, B. Mechanisms of liposomes/water partitioning of (p-methylbenzyl)alkylamines. Pharm Res 1998, 15, (9), 1407-13.

41. Krämer, S. D.; Braun, A.; Jakits-Deiser, C.; Wunderli-Allenspach, H. Towards the predictability of drug-lipid membrane interactions: the $\mathrm{pH}$-dependent affinity of propanolol to phosphatidylinositol containing liposomes. Pharm Res 1998, 15, (5), 739-44.

42. Balon, K.; Riebesehl, B. U.; Muller, B. W. Drug liposome partitioning as a tool for the prediction of human passive intestinal absorption. Pharm Res 1999, 16, (6), 882-8.

43. Marenchino, M.; Alpstag-Wohrle, A. L.; Christen, B.; Wunderli-Allenspach, H.; Kramer, S. D. Alpha-tocopherol influences the lipid membrane affinity of desipramine in a $\mathrm{pH}-$ dependent manner. Eur J Pharm Sci 2004, 21, (2-3), 313-21.

44. Fletcher, K.; Wyatt, I. The composition of lung lipids after poisoning with paraquat. British journal of experimental pathology 1970, 51, (6), 604-10.

45. Sahu, S.; Lynn, W. S. Lipid composition of human alveolar macrophages. Inflammation 1977, 2, (2), 83-91.

46. Korn, E. D. Structure of biological membranes. Science 1966, 153, (3743), 1491-8.

47. Honeybourne, D.; Kees, F.; Andrews, J. M.; Baldwin, D.; Wise, R. The levels of clarithromycin and its 14-hydroxy metabolite in the lung. Eur Respir J 1994, 7, (7), 1275-80.

48. Conte, J. E., Jr.; Golden, J. A.; Duncan, S.; McKenna, E.; Zurlinden, E. Intrapulmonary pharmacokinetics of clarithromycin and of erythromycin. Antimicrob Agents Chemother 1995, $39,(2), 334-8$.

49. Patel, K. B.; Xuan, D.; Tessier, P. R.; Russomanno, J. H.; Quintiliani, R.; Nightingale, C. $\mathrm{H}$. Comparison of bronchopulmonary pharmacokinetics of clarithromycin and azithromycin. Antimicrob Agents Chemother 1996, 40, (10), 2375-9. 
50. Rodvold, K.; Gotfried, M.; Danziger, L.; Servi, R. Intrapulmonary steady-state concentrations of clarithromycin and azithromycin in healthy adult volunteers. Antimicrob. Agents Chemother. 1997, 41, (6), 1399-1402.

51. Hand, W. L.; Corwin, R. W.; Steinberg, T. H.; Grossman, G. D. Uptake of antibiotics by human alveolar macrophages. Am Rev Respir Dis 1984, 129, (6), 933-7.

52. Cohen, A. B.; Cline, M. J. The human alveolar macrophage: isolation, cultivation in vitro, and studies of morphologic and functional characteristics. J Clin Invest 1971, 50, (7), 1390-8.

53. Pratt, S. A.; Smith, M. H.; Ladman, A. J.; Finley, T. N. The ultrastructure of alveolar macrophages from human cigarette smokers and nonsmokers. Lab Invest 1971, 24, (5), 331-8.

54. Hocking, W. G.; Golde, D. W. The pulmonary-alveolar macrophage (first of two parts). N Engl J Med 1979, 301, (11), 580-7.

55. Taylor, A. E.; Finney-Hayward, T. K.; Quint, J. K.; Thomas, C. M.; Tudhope, S. J.; Wedzicha, J. A.; Barnes, P. J.; Donnelly, L. E. Defective macrophage phagocytosis of bacteria in COPD. Eur Respir J 2010, 35, (5), 1039-47.

56. Hodge, S.; Hodge, G.; Ahern, J.; Jersmann, H.; Holmes, M.; Reynolds, P. N. Smoking alters alveolar macrophage recognition and phagocytic ability: implications in chronic obstructive pulmonary disease. Am J Respir Cell Mol Biol 2007, 37, (6), 748-55.

57. van der Deen, M.; de Vries, E. G.; Visserman, H.; Zandbergen, W.; Postma, D. S.; Timens, W.; Timmer-Bosscha, H. Cigarette smoke extract affects functional activity of MRP1 in bronchial epithelial cells. Journal of biochemical and molecular toxicology 2007, 21, (5), 24351.

58. Kosol, S.; Schrank, E.; Krajacic, M. B.; Wagner, G. E.; Meyer, N. H.; Gobl, C.; Rechberger, G. N.; Zangger, K.; Novak, P. Probing the interactions of macrolide antibiotics with membrane-mimetics by NMR spectroscopy. J Med Chem 2012, 55, (11), 5632-6.

59. Joshi, U. M.; Kodavanti, P. R.; Coudert, B.; Dwyer, T. M.; Mehendale, H. M. Types of interaction of amphiphilic drugs with phospholipid vesicles. J Pharmacol Exp Ther 1988, 246, (1), 150-7.

60. Fisar, Z.; Fuksova, K.; Velenovska, M. Binding of imipramine to phospholipid bilayers using radioligand binding assay. Gen Physiol Biophys 2004, 23, (1), 77-99.

61. Vavricka, S. R.; Van Montfoort, J.; Ha, H. R.; Meier, P. J.; Fattinger, K. Interactions of rifamycin SV and rifampicin with organic anion uptake systems of human liver. Hepatology (Baltimore, Md.) 2002, 36, (1), 164-72.

62. Nakanishi, T.; Haruta, T.; Shirasaka, Y.; Tamai, I. Organic cation transporter-mediated renal secretion of ipratropium and tiotropium in rats and humans. Drug Metab Dispos 2011, 39, (1), 117-22.

63. Nickel, S.; Clerkin, C. G.; Selo, M. A.; Ehrhardt, C. Transport mechanisms at the pulmonary mucosa: implications for drug delivery. Expert Opin Drug Deliv 2016, 13, (5), 66790.

64. Ong, H. X.; Traini, D.; Bebawy, M.; Young, P. M. Ciprofloxacin is actively transported across bronchial lung epithelial cells using a Calu-3 air interface cell model. Antimicrob Agents Chemother 2013, 57, (6), 2535-40.

65. Nakamura, T.; Nakanishi, T.; Haruta, T.; Shirasaka, Y.; Keogh, J. P.; Tamai, I. Transport of ipratropium, an anti-chronic obstructive pulmonary disease drug, is mediated by organic cation/carnitine transporters in human bronchial epithelial cells: implications for carriermediated pulmonary absorption. Mol Pharm 2010, 7, (1), 187-95. 
66. Moreau, A.; Le Vee, M.; Jouan, E.; Parmentier, Y.; Fardel, O. Drug transporter expression in human macrophages. Fundamental \& clinical pharmacology 2011, 25, (6), 743-52. 67. Ruark, C. D.; Hack, C. E.; Robinson, P. J.; Mahle, D. A.; Gearhart, J. M. Predicting passive and active tissue:plasma partition coefficients: interindividual and interspecies variability. J Pharm Sci 2014, 103, (7), 2189-98.

68. Schmitt, W. General approach for the calculation of tissue to plasma partition coefficients. Toxicol In Vitro 2008, 22, (2), 457-67.

69. Rodgers, T.; Rowland, M. Physiologically based pharmacokinetic modelling 2: predicting the tissue distribution of acids, very weak bases, neutrals and zwitterions. J Pharm Sci 2006, 95, (6), 1238-57. 